Süleyman Demirel Üniversitesi Fen Edebiyat Fakültesi Fen Dergisi

Süleyman Demirel University Faculty of Arts and Sciences Journal of Science

2021, 16(2): 349-367

DOI: $10.29233 /$ sdufeffd. 938528

Atıf için / For Citation: M. Şahan, N. Emrahoğlu “'Osmaniye'de yedi yıllık dönemde yatay yüzeyde global güneş radyasyonu ölçümleri ve yeni deneysel modeller kullanılarak global güneş radyasyonunun tahmini”, Süleyman Demirel Üniversitesi Fen Edebiyat Fakültesi Fen Dergisi, 16(2), 349-367, 2021.

Araştırma Makalesi

\title{
Osmaniye'de Yedi Yıllık Dönemde Yatay Yüzeydeki Global Güneş Radyasyonu Ölçümleri ve Yeni Ampirik Modeller Kullanılarak Global Güneş Radyasyonunun Tahmini
}

\author{
Muhittin ŞAHAN ${ }^{* 1}$, Nuri EMRAHOĞLU ${ }^{2}$ \\ ${ }^{I}$ Osmaniye Korkut Ata Üniversitesi, Fen Edebiyat Fakültesi, Fizik Bölümü, 80000, Osmaniye, \\ Türkiye \\ ${ }^{2}$ Çukurova Üniversitesi, Eğitim Fakültesi, Matematik ve Fen Bilgisi Eğitimi Bölümü, 01330, \\ Adana, Türkiye
}

*yazışllan yazar e-posta: muhittinsahan@osmaniye.edu.tr

(Alınış: 17.05.2021, Kabul: 05.07.2021, Yayımlanma: 25.11.2021)

Öz: Bu çalışmanın iki önemli amaç içermektedir. Birinci amaç, Osmaniye'de (Enlem, $\phi=$ 36.22K, Boylam=37.04D, yükseklik=118m) 8-48 Model Black\&White piranometresi kullanılarak 2014-2020 yılları arasında yatay yüzeye gelen toplam yedi yıllık bir süre boyunca ölçülen günlük toplam güneş radyasyonunun saatlik ve aylık ortalama değerlerinin sonuçları verilmiştir. 2014-2020 yılları arasındaki günlük toplam güneş radyasyonunun aylık ortalama değerlerinden, yatay yüzeye gelen yıllık aylık toplam ve ortalama güneş 1şınımı sırasıyla 205.01 $\mathrm{MJm}^{-2} \mathrm{~g}^{-1}$ ve $17.08 \mathrm{MJm}^{-2} \mathrm{~g}^{-1}$ olarak hesaplanmıştır. En yüksek aylık global güneş radyasyonu 25.76 $\mathrm{MJm}^{-2} \mathrm{~g}^{-1}$ ile Haziran ayında elde edilirken, en düşük değerler $7.63 \mathrm{MJm}^{-2} \mathrm{~g}^{-1}$ olarak Aralık ayında elde edilmiştir.

İkinci amaç, Osmaniye ili için aylık ortalama güneşlenme süresi (saat), aylık ortalama hava sıcaklığı $\left({ }^{\circ} \mathrm{C}\right)$, en düşük ve en yüksek hava sıcaklıkları $\left({ }^{\circ} \mathrm{C}\right)$, enlem $(\phi)$ ve deklinasyon açısı $(\delta)$ gibi parametreler kullanılarak aylık olarak yıllık global güneş radyasyonunu tahmin etmek için geliştirilen Angström tipi eşitlikler kullanan yedi regresyon modeli (M1-7) vermektir. 19872020 yılları arasını kapsayan meteorolojik parametreler Meteoroloji Genel Müdürlüğ̈̈’nden alınmıştır. Osmaniye için geliştirilen bu modeller, Black\&White piranometresi ile ölçülen günlük toplam güneş radyasyonunun aylık ortalama değerleri kullanılarak kalibre edilmiştir. Tüm modellerden tahmin edilen aylık ortalama toplam güneş 1 şınımların performansları $\mathrm{R}^{2}$ RMSE, MBE, MAPE, MPE, MARE ve MAE istatistik yöntemler kullanılarak karşılaştırılmıştır. M3 modeli $\mathrm{R}^{2}$ ve RMSE istatistiksel hata göstergeleri için en iyi performansı gösterirken, M5 modeli MBE, MPE, MAPE, MARE ve MAE için en iyi performans gösteren modeldir. Buna ek olarak, aylık ortalama günlük açıklık endeks (KT) değerleri, ölçülen global güneş radyasyonu (H) için 0.511 ile 0.634 , M5 modeli için 0.553 ile 0.621 ve M3 modeli için 0.538 ila 0.611 aralığındadır. Sonuçlar, tahmin edilen ve ölçülen toplam güneş 1şınım şiddetinin değerleri arasında oldukça uyumlu olduğunu göstermiştir.

Anahtar kelimeler: Global güneş 1şınımı, Güneş 1şınım tahmin modelleri, Güneşlenme süresi, Açıklık indeksi, Angstrom eşitliği, Korelasyon modelleri 


\title{
Global Solar Radiation Measurements on the Horizontal Surface in Osmaniye During seven Years Period and Global Solar Radiation Estimation Using New Empirical Models
}

\begin{abstract}
This study has two important purposes. The first purpose is to give the results of hourly and monthly mean values of daily global solar radiation measured at the horizontal surface over a period of seven years from 2014 to 2020 at Osmaniye (latitude: $37^{\circ} .04 \mathrm{E}$, longitude: $36^{\circ} .22 \mathrm{~N}$, altitude: $118 \mathrm{~m}$ ), using $8-48$ Model Black\&White pyranometer. From monthly mean values of daily total solar radiation between the years of 2014-2020, annual monthly total and average solar radiation coming to the horizontal surface was calculated as $205.01 \mathrm{MJm}^{-2} \mathrm{~g}^{-1}$ and $17.08 \mathrm{MJm}^{-2} \mathrm{~g}^{-1}$, respectively. While the highest monthly global solar radiation was obtained in June to be $25.76 \mathrm{MJm}^{-2} \mathrm{~g}^{-1}$, the lowest values were obtained in December to be $7.63 \mathrm{MJm}^{-2} \mathrm{~g}^{-1}$.

The second purpose is to give seven regression models (M1-7) which use Angstrom type equations developed to estimate the monthly annual global solar radiation using parameters such as monthly average sunshine duration (hour), monthly average air temperature $\left({ }^{\circ} \mathrm{C}\right)$, lowest and highest air temperatures $\left({ }^{\circ} \mathrm{C}\right)$, latitude $(\phi)$ and solar declination angle $(\delta)$ for Osmaniye province. Meteorological parameters covering the period 1987-2020 were taken from Turkish State Meteorological Service. These models developed for Osmaniye were calibrated using monthly mean values of measured daily total solar radiation, measuring with Black\&White pyranometer. The monthly average total solar radiation performances estimated from the models were compared using statistical methods such as $\mathrm{R}^{2}$, MBE, MAPE, MPE, MARE, and MAE. M3 model shows the best performance for $\mathrm{R}^{2}$ and RMSE statistical error indicators, while M5 model is the best performing model for MBE, MPE, MAPE, MARE and MAE. In addition, the values of the monthly average-daily clearness index (KT) range from 0.511 to 0.634 for measured global solar radiation $(\mathrm{H})$, from 0.553 to 0.621 for M5 model and from 0.538 to 0.611 for M3 model. Results show good agreement between the estimated and measured values of global solar radiation.
\end{abstract}

Key words: Global solar radiation, Solar radiation estimation models, Sunshine hours, Clearness index, Angstrom equation, Correlation models

\section{Giriş}

Güneş enerjisi (ya da güneş radyasyonu), doğrudan güneșten elde edilebilen en önemli enerji kaynaklarından biridir. Güneş enerjisi, güneşin merkezinde meydana gelen nükleer füzyon olayı sonucu güneşin yüzeyine ulaşır ve buradan uzaya yayılır. Güneşin yüzeydeki enerji yoğunluğu yaklaşık $6330 \mathrm{MW} / \mathrm{m}^{2}$ ve dünya atmosferinin dişında güneş ışınımının şiddeti yaklaşık olarak $1370 \mathrm{~W} / \mathrm{m}^{2}$ değerindedir. Atmosferdeki gaz ve tozlar, bulutlar, hava kirliliği gibi diğer faktörler nedeniyle bu enerjinin ancak $0-1100 \mathrm{~W} / \mathrm{m}^{2}$ arasındaki değeri yeryüzüne ulaşır [1-3].

Dünya yüzeyine ulaşan güneş radyasyonu $(\mathrm{H})$, yeryüzündeki tüm canlıların yaşamı için en önemli enerji kaynağıdır. Güneş radyasyonu, buharlaşma, bitki fotosentezi, hidrolojik döngü ve ilgili karasal karbon döngüsü gibi çeşitli yüzey süreçlerini yönetir [4]. Ayrıca, güneş radyasyonu doğadaki en temel yenilenebilir ve temiz enerji kaynağıdır ve fosil yakıtlara alternatif olabilir. Yoğun fosil yakıt kullanımının neden olduğu iklim değişikliği, hidroloji ve ekoloji gibi bazı olumsuz çevresel sorunları hafifletme konusunda büyük potansiyele sahiptir. Ekonomik kalkınmada ve bir toplumun genel refahında çok önemli bir rol oynar. Güneş enerjisi üretimindeki hızlı teknolojik gelişmeler ve maliyetinin düşmesi sonucu, güneş enerjisi gelecekteki enerji 
kaynaklarının kullanılmasında kesinlikle önemli bir rol oynayacaktır [4,5]. Güneş radyasyonu $(\mathrm{H})$ güneş enerjisi sistemleri, iklim değişikliği, tarım, sulama sistemleri, meteoroloji ve ekoloji gibi birçok tasarım çalışmasında oldukça temel ve önemli bir girdi parametresidir [6-8]. Örneğin, tarımsal meteorolojide hassas güneş radyasyon $(\mathrm{H})$ verilerine sahip olunan bir bölge için ürün yetişmesi, verim simülasyonları ve buharlaşma-terleme tahmini için çok önemlidir. Dünya çapında çoğu meteoroloji istasyonda hava sıcaklığı değişimleri düzenli olarak ölçülürken, güneş radyasyonu $(\mathrm{H})$ veya alternatif olarak güneşlenme süreleri çok sınırlı sayıda ölçülmektedir.

Hava sıcaklığı arasındaki yüksek farklılıktan dolayı güneş radyasyonunun $(\mathrm{H})$ tahmini için literatürde bir bazı yöntemler geliştirilmiştir. Ancak bu tahminlerin farklı bölgeler için farklı yöntemler kullanılarak doğruluklarının test edilmesi gerekmektedir $[9,10]$.

$\mathrm{Bu}$ çalışmanın iki temel amacı bulunmaktadır. İlk olarak, Osmaniye Korkut Ata üniversitesi merkez yerleşkesinde (Enlem, $\phi: 37^{\circ} .04227$, Boylam: $36^{\circ} .22134$ ) bulunan 8-48 Model Black\&White piranometre ölçüm cihazı kullanılarak 2014-2020 tarihleri arasında ölçülen toplam yedi yıllık günlük toplam güneş radyasyon verilerinin günlük olarak aylık değişimleri kullanılarak ortalama yıllık güneş radyasyonun $\left(\mathrm{MJm}^{-2} \mathrm{~g}^{-1}\right.$ biriminde) belirlenmiştir [11-13]. İkinci olarak, Devlet Meteoroloji İşleri Genel Müdürlügü'nden elde edilen 1987-2020 yılları arasındaki ortalama sicaklık $\left({ }^{\circ} \mathrm{C}\right)$, ortalama en yüksek sıcaklık $\left({ }^{\circ} \mathrm{C}\right)$, ortalama en düşük sıcaklık $\left({ }^{\circ} \mathrm{C}\right)$ ve ortalama güneşlenme süresi (saat) güneş 1şınım ve Osmaniye'nin enlemi $(\phi)$ ve deklinasyon açısı

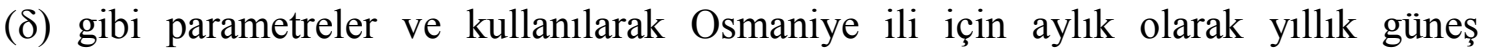
radyasyonunun tahmin için ampirik yöntemler kullanılarak modeller geliştirilmiştir. Daha sonra piranometre ile ölçülen ve ampirik formüllerden elde edilen değerler karşılaştırılmıştır. Modellerden hesaplanan değerlerin doğruluk performansını görmek için korelasyon katsayısı $\left(\mathrm{R}^{2}\right)$, Hata Kareleri Ortalamasının Karekökü (RMSE), Ortalama Yüzde Hata (MPE), Ortalama Taraflı Hata (MBE), Mutlak Hata Oranları Ortalaması (MAPE), Ortalama Mutlak Hata (MAE) ve Ortalama Mutlak Bağıl Hata (MARE) gibi istatistiksel hata yöntemleri kullanılmıştır. Böylece ölçülen ve modellerden hesaplanan değerler karşılaştırılarak en uygun model eşitlikleri elde edilmiştir [14].

Literatürdeki yapılan çalışmalardan anlaşılacağı üzere güneşlenme süresi, hava sıcaklığ1 gibi meteorolojik parametreler güneş radyasyonu üzerinde güçlü bir etkiye sahiptir. Güneşlenme süresi, hava sıcaklığı gibi bazı iklimsel parametreler kullanılarak global güneş radyasyonu elde etmek için geçmişte pek çok çalışma bulunmaktadır [15-22]. Güneşlenme süresine bağlı eşitliklerin genel formülü, yatay yüzeydeki günlük aylık ortalama günlük global güneş 1şınımın $(\mathrm{H})$, yatay bir yüzeydeki aylık ortalama atmosfer dış1 (ya da dünya dış1: extraterrestial) global güneş 1şınımın $\left(\mathrm{H}_{0}\right)$, saat cinsinden ölçülen güneşlenme süresi $(\mathrm{S})$ ve olası maksimum gün uzunluğu $\left(\mathrm{S}_{\mathrm{o}}\right)$ olmak üzere

$$
\frac{H}{H_{0}}=a+b\left(\frac{S}{S_{0}}\right)
$$

olarak verilmektedir. Global güneş radyasyonu ile güneşlenme süresi (S) arasındaki ilişki ilk kez Angström (1924) [15] tarafindan verilmiştir. Daha sonra bu eşitlik Prescott (1940) [16] tarafından Denklem (1)'deki gibi belirtilmiştir. Bu nedenle, bu model Angstrom ve Prescott modeli (A-P model) olarak da bilinmektedir. Burada, a ve b değerleri Angström katsayıları olarak da adlandırılan birimsiz ampirik katsayılardır ve coğrafik enleme bağlı olarak değişmektedirler [15]. $\mathrm{H} / \mathrm{H}_{\mathrm{o}}$ ve $\mathrm{S} / \mathrm{S}_{\mathrm{o}}$ sirasiyla verilen herhangi bir konumdaki meteorolojik güneş radyasyonu ve güneşlenme süresi değişkenlerinin oranlarıdır. $\mathrm{H}$ ve $\mathrm{H}_{\mathrm{o}}$ değerleri $\mathrm{MJm}^{-2} \mathrm{~g}^{-1}$ birimindedir. Yatay bir yüzeye 
gelen ortalama günlük atmosfer dişı global güneş radyasyonu $\left(\mathrm{H}_{0}\right)$ Denklem (2) ile hesaplanır $[1,23]$.

$$
H_{0}=\frac{24 \times 3600 \times G_{s c}}{\pi}\left[1+0.033 \cos \left(\frac{360 D}{365}\right)\right] \times\left[\cos \phi \cos \delta \sin w_{s}+\frac{\pi w_{s}}{180} \sin \phi \sin \delta\right](2)
$$

Burada $\mathrm{G}_{\mathrm{sc}}$ güneş sabiti $\left(=1367 \mathrm{~W} / \mathrm{m}^{2}\right)$, $\mathrm{D}$, Tablo 1'e göre 1 Ocak'tan başlayarak yılın günlerinin sayıs1, $\phi$ ölçüm yapılan yerin enlemi $\left(^{\circ}\right), \delta$ deklinasyon açısı $\left(^{\circ}\right), \omega_{\text {s }}$ güneşin batış açısı (gün batım saat açısı) $\left(^{\circ}\right)$ olarak verilmektedir. Aylık ortalama günlük $\delta$ ve $\omega_{\mathrm{s}}$ açı değerleri sırasıyla Denklem (1) ve Denklem (4) kullanılarak hesaplanabilir.

$$
\begin{gathered}
\delta=23.45 \sin \left[\frac{360}{365}(284+D)\right] \\
w_{s}=\cos ^{-1}[-\tan (\delta) \tan (\phi)]
\end{gathered}
$$

Aylık ortalama günlük maksimum gün uzunluğu (saat/gün) $\left(\mathrm{S}_{0}\right) \omega_{\mathrm{s}}$ açısı kullanılarak Denklem (5) ile hesaplanabilir [1, 24, 25].

$$
S_{o}=\frac{2}{15} w_{s}
$$

Ölçülen global güneş 1şınımı $(\mathrm{H})$ ile atmosfer dışı $\left(\mathrm{H}_{0}\right)$ değerlerini değiştirerek $\mathrm{H} / \mathrm{H}_{0}$ oranı bulunabilir.

Tablo 1. Her ay için önerilen ortalama gün [23].

\begin{tabular}{lcclcc}
\hline \multicolumn{1}{c}{ Ay } & Tarih & D & \multicolumn{1}{c}{ Ay } & Tarih & D \\
\hline Ocak & 17 & 17 & Temmuz & 17 & 198 \\
Şubat & 16 & 47 & Ağustos & 16 & 228 \\
Mart & 16 & 75 & Eylül & 15 & 258 \\
Nisan & 15 & 105 & Ekim & 15 & 288 \\
Mayis & 15 & 135 & Kasım & 14 & 318 \\
Haziran & 11 & 162 & Aralı & 10 & 344 \\
\hline
\end{tabular}

Ölçülen ve tahmin edilen (ya da hesaplanan) aylık global güneş radyasyonu için açıklık indeksi global güneş radyasyonunun atmosfer dışı güneş radyasyonuna orandır $\left(\mathrm{KT}=\mathrm{H} / \mathrm{H}_{0}\right) . \mathrm{H} / \mathrm{H}_{0}$ oran1 gelen global güneş 1şınımı gökyüzüne göre yüzde sapmasını ve belirli bir bölgedeki atmosferik koşullardaki değişiklikleri veren açıklık (netlik) indeksi $\left(\mathrm{K}_{\mathrm{T}}\right)$ olarak bilinir $[2,23]$ ve genel olarak şu şekilde ifade edilmektedir.

$$
K_{T}=\frac{H}{H_{0}}
$$

\section{Materyal ve Metot}

Türkiye'nin iklim ve coğrafik konumu nedeniyle güneş enerjisinin kullanımı için oldukça uygun alternatif bir enerji kaynağı konumundadır. Bu amaçla, özellikle son yıllarda güneş enerjisi potansiyelini belirlemek amaciyla özel kuruluşlarda, üniversitelerde ve değişik devlet kurumlarında önemli araştırmalar yapılmaktadır. Çukurova Üniversitesi ve Osmaniye Korkut Ata Üniversitesi yerleşkelerinde uzun yıllardır Piranometre kullanılarak güneş radyasyon ölçümleri yapılmakta ve yıllık değişimleri incelenmektedir [11-13, 25].

Türkiye'nin güney bölgesinde yer alan Osmaniye ili güneş enerjisi bakımından orta zenginlikte bir ülkedir. Şekil 1'de 2004-2018 yılları arası Türkiye'nin yıllık ortalama 
Global Güneş Radyasyonu dağılım haritası (a) ve Osmaniye ilinin güneş enerjisi potansiyel haritası (b) verilmiştir. Türkiye haritasında görüldügü gibi global güneş radyasyonu şiddetinin dağılımı coğrafik enleme bağlı güneyden kuzeye doğru gidildikçe azalmaktadır. Global güneș radyasyonu şiddetinin dağılımının renk indeki her iki haritanın sağ alt köşelerinde $\mathrm{KWhm}^{-2} \mathrm{~g}^{-1}$ cinsinden verilmiştir. Buna göre, Osmaniye ili ortalama $4.81 \mathrm{KWhm}^{-2} \mathrm{~g}^{-1}\left(17.32 \mathrm{MJm}^{-2} \mathrm{~g}^{-1}\right)$ değerindeki global güneş radyasyonu bakımından Türkiye ortalamasına göre oldukça iyi sahiptir.

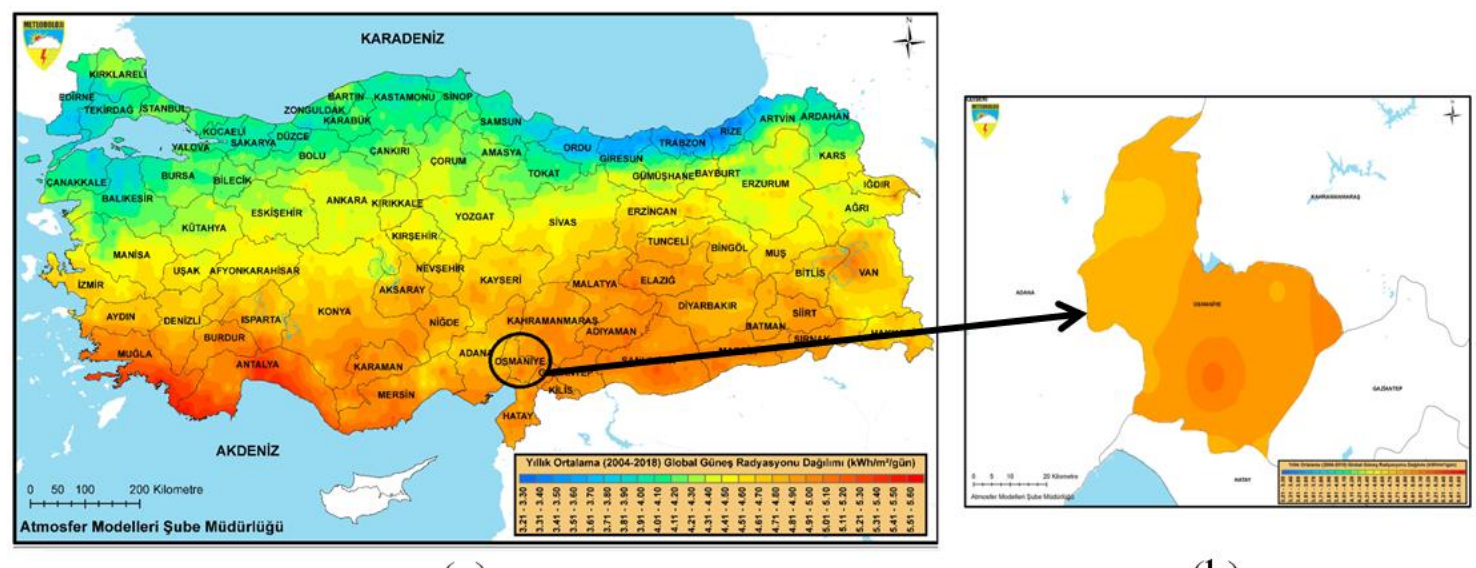

(a)

(b)

Şekil 1. 2004-2018 yılları arası Türkiye'nin yıllık ortalama global güneş radyasyonu dağıllım haritası, b) Osmaniye ilinin güneş enerjisi potansiyel haritas $\left(\mathrm{KWhm}^{-2} \mathrm{~g}^{-1}\right)$ [24].

Güneşten gelen yayılı, direkt ve toplam (global) 1şınım ölçümlerinde pyrheliometreler ve piranometreler yaygın olarak kullanılmaktadır. Güneşten çıkan ve yer yüzünde yatay düzleme gelen global güneş 1şınımı ölçmek ve yıllık olarak değişiminini incelemek amacıyla Osmaniye Korkut Ata Üniversitesi Merkez Karacaoğlan yerleşkesinde (Enlem, $\phi: 37^{\circ} .04227$, Boylam: 36 .22134 ) yerleştirilen 8-48 Model Black\&White piranometre ölçüm cihazı kullanılmıştır. Ölçümlere Mayıs 2013 tarihinde başlanmış ve milivolt $(\mathrm{mV})$ cinsinden dakikalık olarak günlük ölçülmeye başlanmıştır [11-13]. Bu çalışmada, 1 Ocak 2014 ile 31 Aralık 2020 tarihleri arasında toplam yedi yıllık günlük toplam güneş ışınım verilerin aylık değişimleri kullanılmıştır. Gün boyunca dakikalık olarak milivolt cinsinden ölçül verilerin kalibrasyon yapılarak $\mathrm{W} / \mathrm{m}^{2}$ (ya da $\mathrm{MJ} / \mathrm{m}^{2} /$ gün) birimine dönüştürülmüştür. Literatürde, atmosfer dışı 1şımını ve ölçülmüş ya da teorik olarak hesaplanmış günlük güneşlenme süresini kullanarak yer yüzüne gelen global radyasyonu tahmin etmek için lineer [15,16], kuadratik [19], üçüncü dereceden polinom [27], ve logaritmik [28] gibi) çeşitli model türleri geliştirilmiştir.

Güneş radyasyonu ile sıcaklık arasında açık bir ilişki olduğu da bilinmektedir [21,22]. Buna göre güneşlenme arttıkça sıcaklık da ona bağlı olarak artar. Güneşlenmenin düşük olması ya da hiç olmaması ise sıcaklığ 1 önemli ölçüde düşürür. Bu nedenle, gloabal güneş 1şınımını tahmin etmek için güneş 1şınımı ile sıcaklık değişimi arasında ilişki kurulabilir. Bristow ve Campbell (1984) [22], açıklık indeksinin $\left(\mathrm{H} / \mathrm{H}_{0}\right)$ maksimum ve minimum sıcaklık ( $\mathrm{T}_{\operatorname{mak}}$ ve $\mathrm{T}_{\min }$ ) arasındaki ilişkiyi ifade etmişlerdir. Devlet Meteoroloji İşleri Genel Müdürlüğünden elde edilen 1987-2020 yılları arasındaki ortalama sıcaklık $\left({ }^{\circ} \mathrm{C}\right)$, ortalama en yüksek sıcaklık $\left({ }^{\circ} \mathrm{C}\right)$, ortalama en düşük sıcaklık $\left({ }^{\circ} \mathrm{C}\right)$ ve ortalama güneşlenme süresi (saat) güneş 1şınımının tahmin için model hesaplamalarında kullanılmıştır.

Karşılaştırma için kullanılan toplam yedi farklı model eşitlikleri Tablo 2'de verilmiştir. Formüllerdeki değişkenler aylık ortalama güneşlenme süresine $(S)$ ve gün uzunluğuna 
$\left(S_{o}\right)$, ölçüm yapılan yerin enlemine $(\phi)$, deklinasyon açısına $(\delta)$ bağlı olarak değişmektedir. Model 1-7 aralığındaki modeller global güneş radyasyonun atmosfer diş1 global güneş radyasyona oranı $\left(\mathrm{H} / H_{0}\right)$ aylık ortalama güneşlenme süresine $(\mathrm{S})$ ve gün uzunluğuna $\left(\mathrm{S}_{\mathrm{o}}\right)$, ölçüm yapılan yerin enlemine $(\phi)$, güneşin deklinasyon açısına $(\delta)$ bağlı olarak düzenlenmiştir.

Tablo 2. Karş1laştırma için kullanılan toplam yedi farklı model formülleri

\begin{tabular}{cl}
\hline Modeller & \multicolumn{1}{c}{ Eșitlikler } \\
\hline M1 & $H=H_{0}\left[0.199+0.856\left(S / S_{0}\right)+0.021\left(S / S_{0}\right)^{2}-0.362\left(S / S_{0}\right)^{3}\right]$ \\
M2 & $H=H_{0}\left[0.4446+0.265\left(S / S_{0}\right)+0.086 \sin ^{2} \delta\right]$ \\
M3 & $H=H_{0}\left[0.486+0.073\left(S / S_{0}\right)+0.003 T\right]$ \\
M4 & $H=H_{0}\left[0.157+0.426\left(S / S_{0}\right)+0.343 \cos ^{2} \phi\right]$ \\
M5 & $H=H_{0}\left[0.443+0.127\left(S / S_{0}\right)+0.278\left(S / S_{0}\right)^{2}+0.011\left(T_{\max } / T_{\min }\right)\right]$ \\
M6 & $H=H_{0}\left[0.138+0.275\left(S / S_{0}\right)+0.026\left(T_{\max }-T_{\min }\right)\right]$ \\
M7 & $H=H_{0}\left[0.213+0.003 T 0.026\left(T_{\max }-T_{\min }\right)\right]$ \\
\hline
\end{tabular}

Model 1 (M1), sadece aylık ortalama güneşlenme süresine $(\mathrm{S})$ ve gün uzunluğuna $\left(\mathrm{S}_{\mathrm{o}}\right)$ oranının $\left(\mathrm{S} / \mathrm{S}_{\mathrm{o}}\right)$ üçüncü dereceden polinomu (kübik) cinsinden verilmiştir. Model 2 (M2), $\left(\mathrm{S} / \mathrm{S}_{\mathrm{o}}\right)$ oranı ile deklinasyon açısı $(\delta)$ cinsinden verilmiştir. Model $3(\mathrm{M} 3),\left(\mathrm{S} / \mathrm{S}_{\mathrm{o}}\right)$ oranı ile ortalama sicaklık (T) cinsinden verilmiştir. Model $4(\mathrm{M} 4),\left(\mathrm{S} / \mathrm{S}_{\mathrm{o}}\right)$ oranı ile Osmaniye ilinin enlemi $(\phi)$ cinsinden verilmiştir. Model 5 (M5), $\left(\mathrm{S} / \mathrm{S}_{\mathrm{o}}\right)$ oranı ile maksimum sıcaklığın minimum sıcaklığa oranı $\left(\mathrm{T}_{\max } / \mathrm{T}_{\min }\right)$ cinsinden verilmiştir. Model 6 (M6), $\left(\mathrm{S} / \mathrm{S}_{\mathrm{o}}\right)$ oranı ile maksimum sicaklık ile minimum sicaklık arasındaki fark $\left(\mathrm{T}_{\max }{ }^{-}\right.$ $\mathrm{T}_{\text {min }}$ ) cinsinden verilmiştir. Model 7 (M7) ise ortalama sıcaklık (T) ile maksimum sıcaklık ile minimum sıcaklık arasındaki fark $\left(\mathrm{T}_{\max }-\mathrm{T}_{\min }\right)$ cinsinden verilmiştir.

\section{1 İstatistiksel değerlendirme araçları}

Literatürde modellerden hesaplanan güneş radyasyonunun ölçülen değerler ile kıyaslanması ve doğruluğunun test edilmesi için değişik test yöntemleri kullanılmaktadır. Bu çalışmada, Bu çalışmada, farklı modelleri değerlendirmek için Korelasyon Katsayıs1 (Correlation Coefficent: $\mathrm{R}^{2}$ ), Hata Kareleri Ortalamasının Karekökü (Root Mean Square Error: RMSE), Ortalama Taraflı Hata (Mean Bias Error: MBE), Ortalama Yüzde Hata (Mean Percentage Error: MPE) ve Mutlak Hata Oranları Ortalaması (Mean Absolute Percentage Error: MAPE), Ortalama Mutlak Bağıl Hata (Mean Absolute Relative Error: MARE) ve Ortalama Mutlak Hata (Mean Absolute Error: MAE) gibi yedi farklı istatistiksel hata yöntemi kullanılmıştır [14]. Bu nicel göstergeler aşağıda kısaca özetlenmiştir.

$$
\begin{gathered}
R^{2}=1-\frac{\sum_{i=1}^{n}\left(H_{i, \ddot{o}}-H_{i, h}\right)^{2}}{\sum_{i=1}^{n}\left(H_{i, o}-\bar{H}_{i, \ddot{o}}\right)^{2}} \\
R M S E=\sqrt{\frac{1}{n} \sum_{i=1}^{n}\left(H_{i, \ddot{o}}-H_{i, h}\right)^{2}}\left(\mathrm{MJm}^{-2} \mathrm{~g}^{-1}\right) \\
M P E=\frac{1}{n}\left[\sum_{i=1}^{n} \frac{\left(H_{i, \ddot{o}}-H_{i, h}\right)}{H_{i, o}}\right] \times 100 \quad(\%)
\end{gathered}
$$




$$
\begin{gathered}
M B E=\frac{1}{n} \sum_{i=1}^{n}\left(H_{i, \ddot{o}}-H_{i, h}\right) \quad\left(\mathrm{MJm}^{-2} \mathrm{~g}^{-1}\right) \\
M A P E=\frac{1}{n} \sum_{i=1}^{n}\left|\frac{\left(H_{i, \ddot{o}}-H_{i, h}\right)}{H_{i, \ddot{o}}}\right| \times 100 \quad(\%) \\
M A R E=\frac{1}{n} \sum_{i=1}^{n}\left|\frac{\left(H_{i, o}-H_{i, h}\right)}{H_{i, \ddot{o}}}\right|\left(\mathrm{MJm}^{-2} \mathrm{~g}^{-1}\right) \\
M A E=\frac{1}{n} \sum_{i=1}^{n}\left(\bar{H}_{i, \ddot{o}}-\bar{H}_{i, h}\right) \quad\left(\mathrm{MJm}^{-2} \mathrm{~g}^{-1}\right)
\end{gathered}
$$

Burada $H_{i, o}$ and $H_{i, h}$ sırasıyla i.inci ölçülen ve modellerden hesaplanan güneş radyasyon değerlerini göstermektedir $\left(\mathrm{MJm}^{-2} \mathrm{~g}^{-1}\right)$. Daha iyi veri modelleme sonuçları için, istatistiksel hata parametreleri sıfıra yakın olması gerekir. Ancak $\mathrm{R}^{2} 1$ 'e yaklaşmalıdır. $\mathrm{R}^{2}$ göstergesi genellikle modellerin performansını tahmin etmek için kullanılan bir istatistiksel yöntemdir. 0 ile 1 arasında değişmekte ve bu değerin 1'e yaklaşması model tahminleri ile ölçüm değerleri arasındaki bağımlılığın kuvvetli olduğu anlamına gelmektedir. RMSE değeri ne kadar düşükse (sıfıra yaklaşması), mutlak sapması açısından bir modelin öngörü yeteneği o kadar iyidir. MBE, modelin güneş radyasyonu çok düşük (negatif değer) ya da çok yüksek (pozitif değer) eğilimde olmayı ifade ederken, sıfıra en yakın değerde olursa performans göstergesi o kadar yüksek olur. MPE ölçülen ve hesaplanan değerler arasındaki sapmaların yüzde olarak değerini gösterir ve sıfıra ne kadar yakınsa performans göstergesi o kadar yüksek olur. MAPE göstergesi MPE değerinin mutlak değerine eşittir ve sıfıra ne kadar yakınsa performans göstergesi o kadar yüksek olur. MARE yüzde olarak ifade edildiğinde, MAPE olarak da bilinir. MARE göstergesi ölçülen ile modellerden tahmin edilen güneş radyasyonları arasındaki göreceli farklılıkların ortalama mutlak değeri olarak ifade edilir. MAE, göstergesi ölçülen ile modellerden tahmin edilen güneş radyasyonların ortalamaları arasındaki göreceli farklılıkların toplamının gözlem sayısına bölünmesidir ve MBE'nin mutlak değeridir. MBE ve MPE istatistiksel değerleri tahmini değerlerin çok fazla ve çok eksik tahmin edilmesi hakkında bilgi sağlamaktadır.

\section{Bulgular}

\subsection{Güneş radyasyonun ölçülmesi}

Bu çalışmada, 8-48 Model Black\&White piranometre ölçüm cihazı kullanılarak 20142020 arasında ölçülen günlük güneş radyasyon verileri analiz edilmiş ve yıllara göre saatlik olarak günlük ortalama ve toplam $\left(\mathrm{MJm}^{-2} \mathrm{~g}^{-1}\right.$ biriminde) değişimleri elde edilmiştir [11-13]. Elde edilen saatlik olarak ortalama değişimler Tablo 3'de ve Şekil 2 'de verilmiştir. Tablo 3'de yıllara göre saatlik değişimler ve son sütunda ise yedi yıllık ortalama saatlik değişimlerin ortalamaları $\mathrm{MJm}^{-2} \mathrm{~g}^{-1}$ cinsinden verilmiştir.

Tablo 3 ve Şekil 2 incelendiğinde, 2014 yılında saatlik güneş radyasyonu toplam 17.15 $\mathrm{MJm}^{-2} \mathrm{~g}^{-1}$ (ortalama $1.154 \mathrm{MJm}^{-2} \mathrm{~g}^{-1}$ ) olarak ölçülmüştür. En düşük ve en yüksek güneş radyasyon değerleri sirasıyla saat 05:00-06:00' da arasında $0.09 \mathrm{MJm}^{-2} \mathrm{~g}^{-1}$ ve saat 12:0013:00'da arasında $2.29 \mathrm{MJm}^{-2} \mathrm{~g}^{-1}$ olarak ölçülmüştür. 2015 yılında saatlik güneş radyasyonu toplam $16.71 \mathrm{MJm}^{-2} \mathrm{~g}^{-1}$ (ortalama $1.11 \mathrm{MJm}^{-2} \mathrm{~g}^{-1}$ ) olarak ölçülürken, en düşük güneş radyasyon değerleri sabah güneş batımında ve akşam güneş batımında 
(ortalama $0.5 \mathrm{MJm}^{-2} \mathrm{~g}^{-1}$ ) olarak ölçülmüştür. En yüksek güneş radyasyon değeri ise saat 12:00-13:00' da arasında $2.23 \mathrm{MJm}^{-2} \mathrm{~g}^{-1}$ olarak ölçülmüştür. 2016 yılında ölçülen güneş radyasyonlarının ortalama değerlerinin en yüksek değeri 12:00-13:00'da arasında 2.44 $\mathrm{MJm}^{-2} \mathrm{~g}^{-1}$ olarak ölçülürken günlük ortalama toplam radyasyon $18.29 \mathrm{MJm}^{-2} \mathrm{~g}^{-1}$ olarak ölçülmüştür. 2017 y1lında ölçülen ortalama toplam güneş radyasyon değeri $17.83 \mathrm{MJm}^{-}$ ${ }^{2} \mathrm{~g}^{-1}$ (ortalama $1.19 \mathrm{MJm}^{-2} \mathrm{~g}^{-1}$ ) olarak ölçülürken en yüksek radyasyon $2.36 \mathrm{MJm}^{-2} \mathrm{~g}^{-1}$ olarak saat 12:00-13:00'da arasında ölçülmüştür. 2018 yılında ölçülen güneş radyasyonun ortalama değerleri toplam olarak $16.95 \mathrm{MJm}^{-2} \mathrm{~g}^{-1}$ (ortalama $1.13 \mathrm{MJm}^{-2} \mathrm{~g}^{-1}$ ) olarak ölçülürken en yüksek radyasyon $2.28 \mathrm{MJm}^{-2} \mathrm{~g}^{-1}$ olarak saat 12:00-13:00'da ölçülmüştür. 2019 y1lında ortalama güneş radyasyon değerlerin toplamı $17.96 \mathrm{MJm}^{-2} \mathrm{~g}^{-1}$ (ortalama 1.20 $\mathrm{MJm}^{-2} \mathrm{~g}^{-1}$ ) olarak ölçülürken en yüksek radyasyon $2.22 \mathrm{MJm}^{-2} \mathrm{~g}^{-1}$ olarak saat 12:00-13:00' da ölçülmüştür. 2020 y1lında ortalama güneş radyasyon değerlerin toplamı $16.92 \mathrm{MJm}^{-2} \mathrm{~g}^{-1}$ (ortalama $1.13 \mathrm{MJm}^{-2} \mathrm{~g}^{-1}$ ) olarak ölçülürken en yüksek radyasyon 2.20 $\mathrm{MJm}^{-2} \mathrm{~g}^{-1}$ olarak saat 12:00-13:00' da ölçülmüştür. Tablo 3'de son sütundaki 2014-2020 yılları arasındaki saatlik ortalama değişimlerin toplamları saat 12:00-13:00 arasında toplam 16.02 $\mathrm{MJm}^{-2} \mathrm{~g}^{-1}$ olduğu, en düşük değerin 2020 y1lında $\left(2.20 \mathrm{MJm}^{-2} \mathrm{~g}^{-1}\right)$ ve en yüksek değerin $\left(2.44 \mathrm{MJm}^{-2} \mathrm{~g}^{-1}\right) 2016$ y1lında olduğu görülmüştür.

2014-2020 arasında ölçülen günlük güneş radyasyon $(H)$ değişim verilerinin saatlik olarak toplam değişimleri Tablo 4'de ve Şekil 3'de verilmiştir. Tablo 4'de yıllara göre saatlik toplam değişimler ve son sütunda ise yedi yıllık saatlik olarak toplam değişimlerin ortalamaları $\mathrm{MJm}^{-2} \mathrm{~g}^{-1}$ cinsinden verilmiştir. Tablo 4 ve Şekil 3 incelendiğinde, 2014 y1lı boyunca ölçülen günlük güneş radyasyon değişimlerinin saatlik olarak toplamları $205.75 \mathrm{MJm}^{-2} \mathrm{~g}^{-1}$ (ortalama $13.72 \mathrm{MJm}^{-2} \mathrm{~g}^{-1}$ ) olarak ölçülmüştür. Saat 12:00-13:00' da arasında $27.49 \mathrm{MJm}^{-2} \mathrm{~g}^{-1}$ ile en yüksek olarak ölçülmüştür. 2015 y1lında saatlik güneş radyasyon değerlerini toplamı $197.83 \mathrm{MJm}^{-2} \mathrm{~g}^{-1}$ (ortalama $13.19 \mathrm{MJm}^{-2} \mathrm{~g}^{-1}$ ) olarak ölçülürken, en yüksek güneş radyasyon değeri saat 12:00-13:00' da arasında 26.81 $\mathrm{MJm}^{-2} \mathrm{~g}^{-1}$ olarak ölçülmüştür. 2016 yılında ölçülen güneş radyasyonlarının toplam değerlerinin en yüksek değeri 12:00-13:00'da arasında 29.25 $\mathrm{MJm}^{-2} \mathrm{~g}^{-1}$ olarak ölçülürken günlük toplam radyasyon $219.50 \mathrm{MJm}^{-2} \mathrm{~g}^{-1}$ (ort. $14.63 \mathrm{MJm}^{-}$ ${ }^{2} \mathrm{~g}^{-1}$ ) olarak ölçülmüştür. 2017 yılında ölçülen yıllık toplam güneş radyasyon değerinin toplamı $211.20 \mathrm{MJm}^{-2} \mathrm{~g}^{-1}$ (ortalama $14.08 \mathrm{MJm}^{-2} \mathrm{~g}^{-1}$ ) olarak ölçülürken en yüksek radyasyon $28.26 \mathrm{MJm}^{-2} \mathrm{~g}^{-1}$ olarak saat 12:00-13:00'da arasında ölçülmüştür. 2018 yılında ölçülen güneş radyasyonun ortalama değerleri toplam olarak $203.44 \mathrm{MJm}^{-2} \mathrm{~g}^{-1}$ (ortalama $13.56 \mathrm{MJm}^{-2} \mathrm{~g}^{-1}$ ) olarak ölçülürken en yüksek radyasyon $27.33 \mathrm{MJm}^{-2} \mathrm{~g}^{-1}$ olarak saat 12:00-13:00'da ölçülmüştür. 2019 yılında günlük güneş radyasyon değerlerinin saatlik toplamları $207.46 \mathrm{MJm}^{-2} \mathrm{~g}^{-1}$ (ortalama $13.83 \mathrm{MJm}^{-2} \mathrm{~g}^{-1}$ ) olarak ölçülürken en yüksek radyasyon $26.59 \mathrm{MJm}^{-2} \mathrm{~g}^{-1}$ olarak saat 12:00-13:00' da ölçülmüștür. 2020 günlük güneş radyasyon değerlerinin saatlik toplamları ise 203.02 $\mathrm{MJm}^{-2} \mathrm{~g}^{-1}$ (ortalama $13.53 \mathrm{MJm}^{-2} \mathrm{~g}^{-1}$ ) olarak ölçülürken en yüksek radyasyon 26.45 $\mathrm{MJm}^{-2} \mathrm{~g}^{-1}$ olarak saat 12:00-13:00' da ölçülmüştür.

Tablo 4'de son sütundaki 2014-2020 yılları arasındaki günlük olarak saatlik toplam değişimlerine bakıldığında 12:00-13:00 saatleri arasındaki toplamı $192.18 \mathrm{MJm}^{-2} \mathrm{~g}^{-1}$ olduğu, en düşük değerin 2020 yılında $\left(26.45 \mathrm{MJm}^{-2} \mathrm{~g}^{-1}\right)$ ve en yüksek değerin $(29.25$ $\mathrm{MJm}^{-2} \mathrm{~g}^{-1}$ ) 2016 yılında olduğu görülmüştür. 2014-2020 yılları arasındaki ortalama yıllık olarak saatlik toplamları $1448.19 \mathrm{MJm}^{-2} \mathrm{~g}^{-1}$ ve ortalamaları $96.55 \mathrm{MJm}^{-2} \mathrm{~g}^{-1}$ olduğu bulunmuştur.

2014-2020 arasında ölçülen günlük güneş radyasyon verilerinin aylık olarak ortalama değişimleri Tablo 5'de ve Şekil 4'de verilmiştir. Tablo 5'de yıllara göre aylik olarak toplam değişimler ve son iki sütunda ise yedi yıllık aylık olarak toplam değişimlerin toplamları ve ortalamaları verilmiştir. Tablo 4 ve Şekil 3 incelendiğinde, 2014 yılında 
aylık güneş radyasyonu toplam $203.53 \mathrm{MJm}^{-2} \mathrm{~g}^{-1}$ (ortalama $16.96 \mathrm{MJm}^{-2} \mathrm{~g}^{-1}$ ) olarak ölçülmüsstür. En düşük ve en yüksek güneş radyasyon değerleri sırasıyla Aralık (7.31 $\mathrm{MJm}^{-2} \mathrm{~g}^{-1}$ ) ve Haziran (25.99 $\mathrm{MJm}^{-2} \mathrm{~g}^{-1}$ ) aylarında ölçülmüştür. 2015 yılında aylık güneş radyasyonu $(\mathrm{H})$ toplam $195.83 \mathrm{MJm}^{-2} \mathrm{~g}^{-1}$ (ortalama $16.32 \mathrm{MJm}^{-2} \mathrm{~g}^{-1}$ ) olarak ölçülmüştür. Güneş radyasyonun en düşük ve en yüksek değerleri ise sırasıyla Aralık (7.49 $\mathrm{MJm}^{-2} \mathrm{~g}^{-1}$ ) ve Temmuz $\left(25.15 \mathrm{MJm}^{-2} \mathrm{~g}^{-1}\right)$ aylarında ölçülmüştür. 2016 yılında aylık olarak ölçülen güneş radyasyonunun aylık toplamı $214.57 \mathrm{MJm}^{-2} \mathrm{~g}^{-1}$ (ort. $17.88 \mathrm{MJm}^{-2} \mathrm{~g}^{-1}$ ) olarak ölçülürken en düşük ve en yüksek ölçüldüğü aylar ise $7.39 \mathrm{MJm}^{-2} \mathrm{~g}^{-1}$ ile Aralık ayı ve 27.07 $\mathrm{MJm}^{-2} \mathrm{~g}^{-1}$ ile Haziran ayı olmuştur. 2017 yılında ölçülen aylık ortalama yıllık güneş radyasyonunun toplamı $211.20 \mathrm{MJm}^{-2} \mathrm{~g}^{-1}$ ve ortalaması $17.60 \mathrm{MJm}^{-2} \mathrm{~g}^{-1}$ olarak ölçülmüştür. 2017 yılında en yüksek Temmuz'da $28.04 \mathrm{MJm}^{-2} \mathrm{~g}^{-1}$ ve en düşük ise Aralık'ta 6.41 $\mathrm{MJm}^{-2} \mathrm{~g}^{-1}$ olduğu görülmüştür. 2018 y1lında aylık olarak toplam güneş radyasyonu $203.44 \mathrm{MJm}^{-2} \mathrm{~g}^{-1}$ (ortalama $16.95 \mathrm{MJm}^{-2} \mathrm{~g}^{-1}$ ) olarak elde edilmiştir. En düşük ve en yüksek değerleri ise sirasıyla Haziran $\left(25.99 \mathrm{MJm}^{-2} \mathrm{~g}^{-1}\right)$ ve Aralık $\left(6.23 \mathrm{MJm}^{-2} \mathrm{~g}^{-1}\right)$ aylarında olduğu görülmektedir. 2019 yılında aylık olarak toplam güneş radyasyonu 203.46 $\mathrm{MJm}^{-2} \mathrm{~g}^{-1}$ (ortalama 16.95 $\mathrm{MJm}^{-2} \mathrm{~g}^{-1}$ ) olarak elde edilmistir. 6.495 $\mathrm{MJm}^{-2} \mathrm{~g}^{-1}$ ile Aralık ayında en düşük radyasyon elde edilirken $25.03 \mathrm{MJm}^{-2} \mathrm{~g}^{-1}$ ile en yüksek Temmuz ayında ölçülmüştür. 2020 yılında ise yıllık olarak ölçülen aylık ortalama toplam güneş radyasyonu $203.02 \mathrm{MJm}^{-2} \mathrm{~g}^{-1}$ (ortalama $16.92 \mathrm{MJm}^{-2} \mathrm{~g}^{-1}$ ) olarak elde edilmiş ve 24.57 $\mathrm{MJm}^{-2} \mathrm{~g}^{-1}$ ile en yüksek Haziran ayında ve $9.65 \mathrm{MJm}^{-2} \mathrm{~g}^{-1}$ ile en düşük Aralık ayında ölçülmüştür.

Tablo 3. 2014-2020 arasında piranometre ile ölçülen günlük güneş radyasyon verilerinin yıllara göre saatlik olarak günlük ortalama değişimleri $\left(\mathrm{MJm}^{-2} \mathrm{~g}^{-1}\right)$.

\begin{tabular}{lllllllll}
\hline Zaman (sa) & $\mathbf{2 0 1 4}$ & $\mathbf{2 0 1 5}$ & $\mathbf{2 0 1 6}$ & $\mathbf{2 0 1 7}$ & $\mathbf{2 0 1 8}$ & $\mathbf{2 0 1 9}$ & $\mathbf{2 0 2 0}$ & ORT. \\
\hline $\mathbf{5 - 6}$ & 0.09 & 0.05 & 0.07 & 0.14 & 0.06 & 0.34 & 0.19 & 0.13 \\
$\mathbf{6 - 7}$ & 0.16 & 0.16 & 0.18 & 0.19 & 0.19 & 0.29 & 0.23 & 0.20 \\
$\mathbf{7 - 8}$ & 0.55 & 0.53 & 0.60 & 0.53 & 0.53 & 0.64 & 0.48 & 0.55 \\
$\mathbf{8 - 9}$ & 1.06 & 1.08 & 1.17 & 1.04 & 1.03 & 1.09 & 0.97 & 1.06 \\
$\mathbf{9 - 1 0}$ & 1.56 & 1.59 & 1.71 & 1.56 & 1.56 & 1.59 & 1.49 & 1.58 \\
$\mathbf{1 0 - 1 1}$ & 1.95 & 1.96 & 2.09 & 1.99 & 1.97 & 1.93 & 1.90 & 1.97 \\
$\mathbf{1 1 - 1 2}$ & 2.21 & 2.16 & 2.35 & 2.24 & 2.23 & 2.16 & 2.14 & 2.21 \\
$\mathbf{1 2 - 1 3}$ & 2.29 & 2.23 & 2.44 & 2.36 & 2.28 & 2.22 & 2.20 & 2.29 \\
$\mathbf{1 3 - 1 4}$ & 2.19 & 2.09 & 2.34 & 2.27 & 2.16 & 2.03 & 2.09 & 2.17 \\
$\mathbf{1 4 - 1 5}$ & 1.90 & 1.80 & 2.03 & 2.01 & 1.91 & 1.78 & 1.83 & 1.90 \\
$\mathbf{1 5 - 1 6}$ & 1.43 & 1.39 & 1.55 & 1.57 & 1.49 & 1.39 & 1.44 & 1.46 \\
$\mathbf{1 6 - 1 7}$ & 0.92 & 0.87 & 0.97 & 1.03 & 0.92 & 0.91 & 0.97 & 0.94 \\
$\mathbf{1 7 - 1 8}$ & 0.50 & 0.53 & 0.51 & 0.62 & 0.42 & 0.63 & 0.54 & 0.53 \\
$\mathbf{1 8 - 1 9}$ & 0.23 & 0.23 & 0.20 & 0.22 & 0.13 & 0.48 & 0.28 & 0.25 \\
$\mathbf{1 9 - 2 0}$ & 0.11 & 0.06 & 0.09 & 0.06 & 0.05 & 0.47 & 0.17 & 0.15 \\
\hline
\end{tabular}




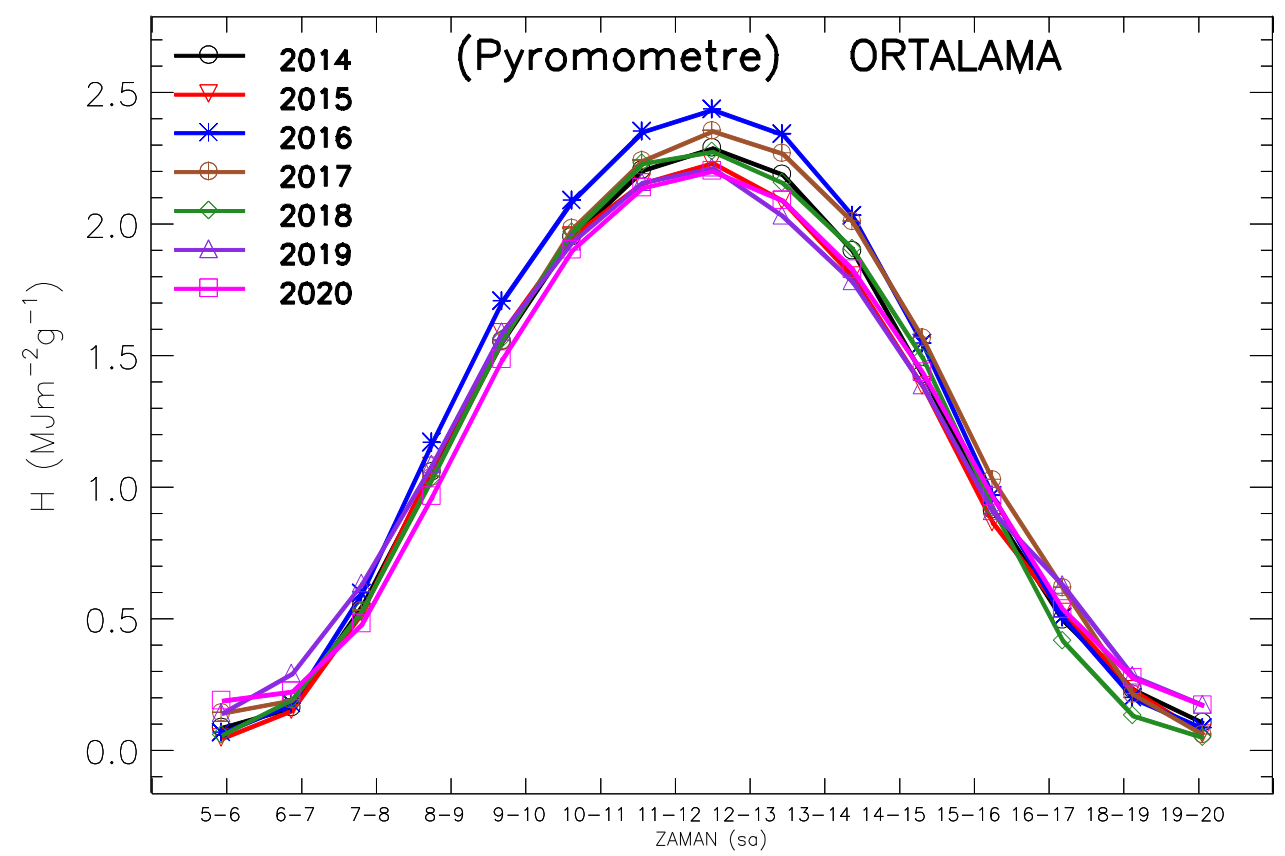

Şekil 2. 2014-2020 arasında ölçülen günlük güneş radyasyon verilerinin yıllara göre saatlik olarak günlük ortalama değişimleri.

Tablo 5'de son iki sütunda verilen 2014-2020 yılları arasındaki yedi yıllık olarak aylık toplamlar ve ortalama aylık güneş radyasyon değişimlerinin günlük olarak aylık değişimi verilmiștir. Toplamları incelendiğinde aylara göre yedi y1llık toplamları $1435.04 \mathrm{MJm}^{-2} \mathrm{~g}^{-1}$ (ortalama $119.59 \mathrm{MJm}^{-2} \mathrm{~g}^{-1}$ ) olduğu görülüştür. 2014-2020 arasında ölçülen global güneş radyasyon değerlerinin toplam $205.01 \mathrm{MJm}^{-2} \mathrm{~g}^{-1}$ ve ortalama 17.08 $\mathrm{MJm}^{-2} \mathrm{~g}^{-1}$ olarak ölçülürken en yüksek ve en düşük olduğu aylar sırasıyla Haziran (25.76 $\mathrm{MJm}^{-2} \mathrm{~g}^{-1}$ ) ve Aralık (7.63 $\mathrm{MJm}^{-2} \mathrm{~g}^{-1}$ ) ayları olmuştur. Tablo 5'de son sütunda verilen aylara göre yedi y1llık ortalama güneş radyasyonun değiş̧imi Şekil 4'de içi dolu çember ve çizgi-çizgi olarak verilmiştir.

Tablo 4. 2014-2020 arasında piranometre ile ölçülen günlük güneş radyasyon $(\mathrm{H})$ verilerinin yıllara göre saatlik olarak günlük toplam değişimleri $\left(\mathrm{MJm}^{-2} \mathrm{~g}^{-1}\right)$.

\begin{tabular}{lllllllll}
\hline Zaman (sa) & $\mathbf{2 0 1 4}$ & $\mathbf{2 0 1 5}$ & $\mathbf{2 0 1 6}$ & $\mathbf{2 0 1 7}$ & $\mathbf{2 0 1 8}$ & $\mathbf{2 0 1 9}$ & $\mathbf{2 0 2 0}$ & ORT. \\
\hline $\mathbf{5 - 6}$ & 1.07 & 0.58 & 0.82 & 1.73 & 0.72 & 4.12 & 2.30 & 1.62 \\
$\mathbf{6 - 7}$ & 1.97 & 1.86 & 2.15 & 2.33 & 2.34 & 3.52 & 2.70 & 2.41 \\
$\mathbf{7 - 8}$ & 6.61 & 6.30 & 7.19 & 6.39 & 6.39 & 7.63 & 5.80 & 6.62 \\
$\mathbf{8 - 9}$ & 12.72 & 12.96 & 14.05 & 12.47 & 12.42 & 13.06 & 11.61 & 12.76 \\
$\mathbf{9 - 1 0}$ & 18.67 & 19.05 & 20.50 & 18.70 & 18.76 & 19.10 & 17.85 & 18.95 \\
$\mathbf{1 0 - 1 1}$ & 23.44 & 23.47 & 25.09 & 23.82 & 23.65 & 23.21 & 22.84 & 23.65 \\
$\mathbf{1 1 - 1 2}$ & 26.48 & 25.90 & 28.24 & 26.91 & 26.79 & 25.93 & 25.68 & 26.56 \\
$\mathbf{1 2 - 1 3}$ & 27.49 & 26.81 & 29.25 & 28.26 & 27.33 & 26.59 & 26.45 & 27.45 \\
$\mathbf{1 3 - 1 4}$ & 26.29 & 25.09 & 28.12 & 27.24 & 25.90 & 24.39 & 25.11 & 26.02 \\
$\mathbf{1 4 - 1 5}$ & 22.81 & 21.65 & 24.39 & 24.13 & 22.90 & 21.39 & 21.95 & 22.75 \\
$\mathbf{1 5 - 1 6}$ & 17.14 & 16.63 & 18.56 & 18.83 & 17.92 & 16.66 & 17.26 & 17.57 \\
$\mathbf{1 6 - 1 7}$ & 10.99 & 10.40 & 11.63 & 12.36 & 11.08 & 10.92 & 11.59 & 11.28 \\
$\mathbf{1 7 - 1 8}$ & 5.97 & 5.26 & 6.07 & 6.20 & 5.02 & 5.66 & 6.46 & 5.81 \\
$\mathbf{1 8 - 1 9}$ & 2.81 & 1.62 & 2.41 & 1.51 & 1.61 & 2.91 & 3.33 & 2.31 \\
$\mathbf{1 9 - 2 0}$ & 1.28 & 0.25 & 1.03 & 0.31 & 0.61 & 2.37 & 2.08 & 1.13 \\
\hline
\end{tabular}




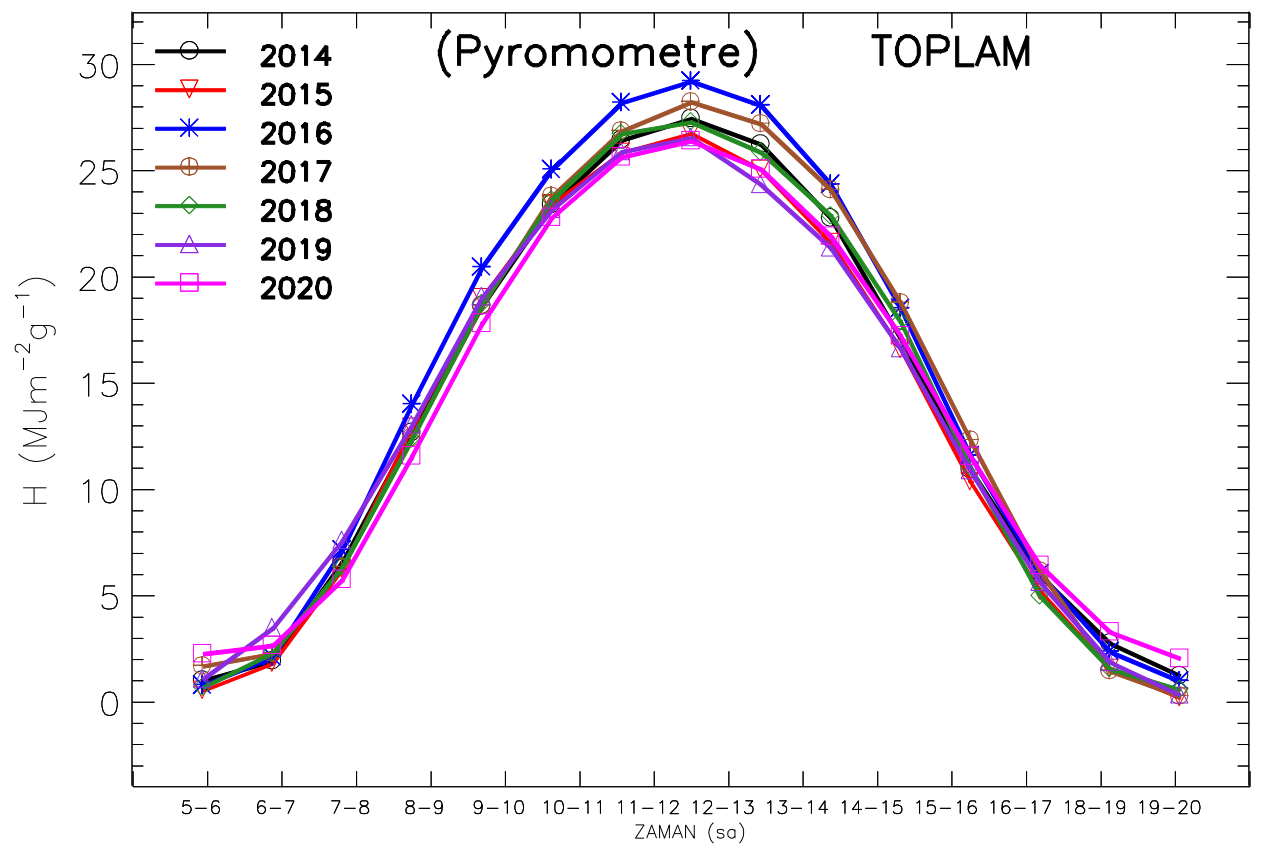

Şekil 3. 2014-2020 arasında ölçülen günlük güneş radyasyon verilerinin yıllara göre saatlik olarak günlük toplam değişimleri.

\subsection{Güneş radyasyonun tahmini içim model hesaplamalart}

Devlet Meteoroloji İşleri Genel Müdürlüğünden elde edilen 1987-2020 (33 yıllık) yılları arasındaki ortalama maksimum, ortalama minimum ve ortalama sicaklık $\left({ }^{\circ} \mathrm{C}\right)$ verileri ile ortalama güneşlenme süresi (saat) verileri alınmıştır. Bu veriler Osmaniye $\left(\phi=37^{\circ} .04227\right)$ ilinin aylık olarak ortalama güneş radyasyonu tahmin etmek için yedi farklı ampirik formül modeli kullanılmıştır (Tablo 2). M1 ile M7 arasında isimlendirilen bu ampirik eşitliklerden hesaplanan aylık olarak ortalama toplam güneş radyasyon verilerinin doğruluğunu test etmek için Tablo 5'de son sütunda verilen Osmaniye ili için piranometre ile ölçülen 2014-2020 arasında yedi yıllık güneş radyasyon verilerinin ortalama $(\mathrm{H})$ değerleri $\left(\mathrm{MJm}^{-2} \mathrm{~g}^{-1}\right)$ kullanılmıştır. Modellerden elde edilen hesaplanmış aylık ortalama güneş radyasyon sonuçları Tablo 6'da verilmiştir. Tablo 6'da ikinci Denklem (2)'den hesaplanan atmosfer dışı güneş radyasyonu $\left(\mathrm{H}_{0}\right)$ ve üçüncü sütunda Tablo 4'deki son sütunda verilen yedi y1llık (2014-2020) ortalama güneş radyasyonu sonuçları $(\mathrm{H})$ verilmiştir. Son yedi sütunda ise Tablo 2'de verilen ampirik formüllerden hesaplanan aylara göre ortalama güneş radyasyonu sonuçları (M1-7) $\mathrm{MJm}^{-2} \mathrm{~g}^{-1}$ biriminde verilmiştir. Tablo 6' da verilen modeller (M1-7) ile hesaplan aylik olarak ölçülen günlük ortalama güneş radyasyon değişimlerinin Osmaniye'de piranometre ile ölçülen ortalama aylık olarak ortalama günlük ölçülen güneş radyasyon $(H)$ değerlerin karşılaştırılması Şekil 5'de verilmiştir. Şekil 5'de görüldüğü gibi modellerden hesaplanan güneş radyasyonların aylık değişlerinin ölçülen güneş radyasyonları ile uyum içinde olduğu görülmektedir.

Osmaniye için modellerden hesaplanan güneş radyasyon değerlerinin değişimleri yedi yıllık ölçülen güneş radyasyonlarının ortalaması olan ölçülmüş güneş radyasyonu ile oldukça iyi performans gösterdiğini açıkça göstermektedir. Buna göre, modellerden hesaplanan ve Tablo 6'da verilen aylara göre y1llık güneş radyasyon değerleri kısaca şu şekilde özetlenebilir. M1 modeli ile toplam 202.93 $\mathrm{MJm}^{-2} \mathrm{~g}^{-1}$ (ort. $16.91 \mathrm{MJm}^{-2} \mathrm{~g}^{-1}$ ), M2 ile toplam 205.76 $\mathrm{MJm}^{-2} \mathrm{~g}^{-1}$ (ort. 17.15 $\mathrm{MJm}^{-2} \mathrm{~g}^{-1}$ ), M3 ile toplam 206.03 $\mathrm{MJm}^{-2} \mathrm{~g}^{-1}$ (ort. 17.17 $\mathrm{MJm}^{-2} \mathrm{~g}^{-1}$ ), M4 ile toplam 205.50 $\mathrm{MJm}^{-2} \mathrm{~g}^{-1}$ (ort. 17.12 $\mathrm{MJm}^{-2} \mathrm{~g}^{-1}$ ), M5 ile toplam 210.04 $\mathrm{MJm}^{-2} \mathrm{~g}^{-1}$ (ort. 17.50 $\mathrm{MJm}^{-2} \mathrm{~g}^{-1}$ ), M6 ile toplam 207.19 $\mathrm{MJm}^{-2} \mathrm{~g}^{-1}$ (ort. 17.27 $\mathrm{MJm}^{-}$ ${ }^{2} \mathrm{~g}^{-1}$ ) ve $\mathrm{M} 7$ ile toplam $208.51 \mathrm{MJm}^{-2} \mathrm{~g}^{-1}$ (ort. $17.38 \mathrm{MJm}^{-2} \mathrm{~g}^{-1}$ ) olarak hesaplanmıştır. 
$\mathrm{Bu}$ çalışmada geliştirilen modellerden hesaplanan değerlerin doğruluk performansını görmek amacıyla Eşitlik-7 ile Eşitlik-13 arasında verilen istatistiksel hata yöntemleri kullanılarak [14] R ${ }^{2}$, RMSE, MBE, MPE, MAPE, MARE ve MAE istatistiksel sonuçlar elde edilmiş ve Tablo 7'de verilmiştir. Tablo 7'de verilen modellerin yüzde hata istatistiksel ( $\mathrm{R}^{2}$, MAPE ve MPE) performans göstergelerinin dışındaki diğer istatistiksel hata sonuçları kullanılarak modellere göre $\mathrm{MJm}^{-2} \mathrm{~g}^{-1}$ birimindeki değişimleri de Şekil 6'da verilmiştir. Yukarıda belirtildiği gibi, daha iyi veri modellemesi için $\mathrm{R}^{2}$ mümkün olduğunca l'e ve RMSE, MBE, MPE, MAPE, MARE ve MAE istatistiksel göstergelerin mutlak değerleri sıfıra yaklaşmalıdır.

Tablo 5. 2014-2020 arasında piranometre ile ölçülen günlük güneş radyasyon $(H)$ verilerinin yıllara göre aylık olarak günlük ortalama değişimleri $\left(\mathrm{MJm}^{-2} \mathrm{~g}^{-1}\right)$.

\begin{tabular}{llllllllll}
\hline AYLAR & $\mathbf{2 0 1 4}$ & $\mathbf{2 0 1 5}$ & $\mathbf{2 0 1 6}$ & $\mathbf{2 0 1 7}$ & $\mathbf{2 0 1 8}$ & $\mathbf{2 0 1 9}$ & $\mathbf{2 0 2 0}$ & $\begin{array}{l}\text { Aylık } \\
\text { Top. }\end{array}$ & $\begin{array}{l}\text { Aylık } \\
\text { Ort. }\end{array}$ \\
\hline Ocak & 9.01 & 7.94 & 7.87 & 8.85 & 8.14 & 7.92 & 10.05 & 59.79 & 8.54 \\
Şubat & 13.26 & 9.51 & 11.44 & 13.77 & 10.13 & 11.21 & 10.87 & 80.2 & 11.46 \\
Mart & 15.82 & 14.48 & 16.49 & 14.7 & 15.3 & 15.74 & 13.81 & 106.35 & 15.19 \\
Nisan & 20.48 & 19 & 22.3 & 20.15 & 20.9 & 20.26 & 18.76 & 141.84 & 20.26 \\
Mayıs & 23.82 & 24.15 & 23.65 & 23.73 & 23.83 & 23.46 & 23.52 & 166.16 & 23.74 \\
Haziran & 25.99 & 24.02 & 26.92 & 27.88 & 25.99 & 24.96 & 24.57 & 180.33 & 25.76 \\
Temmuz & 23.69 & 25.15 & 27.07 & 28.04 & 25.93 & 25.03 & 24.06 & 178.97 & 25.57 \\
Ağustos & 22.06 & 21.52 & 23.29 & 22.63 & 24.36 & 23.24 & 23.73 & 160.82 & 22.97 \\
Eylül & 17.84 & 17.83 & 20.85 & 19.74 & 19.44 & 20.33 & 18.73 & 134.76 & 19.25 \\
Ekim & 13.8 & 12.65 & 15.44 & 15.31 & 13.84 & 13.82 & 14.37 & 99.23 & 14.18 \\
Kasım & 10.45 & 10.08 & 11.86 & 9.99 & 9.35 & 10.53 & 10.9 & 73.17 & 10.45 \\
Aralık & 7.31 & 9.49 & 7.39 & 6.41 & 6.23 & 6.95 & 9.65 & 53.42 & 7.63 \\
\hline Yllık & 203.53 & 195.83 & 214.57 & 211.2 & 203.44 & 203.46 & 203.02 & 1435.04 & 205.01 \\
Top. & 16.96 & 16.32 & 17.88 & 17.6 & 16.95 & 16.95 & 16.92 & 119.59 & 17.08 \\
Yıllık Ort. & 25.99 & 25.15 & 27.07 & 28.04 & 25.99 & 25.03 & 24.57 & 181.86 & 25.76 \\
Mak. & 25.96 & 7.94 & 7.39 & 6.41 & 6.23 & 6.95 & 9.65 & 51.88 & 7.63 \\
Min. & 7.31 & 7.94 & & & & &
\end{tabular}




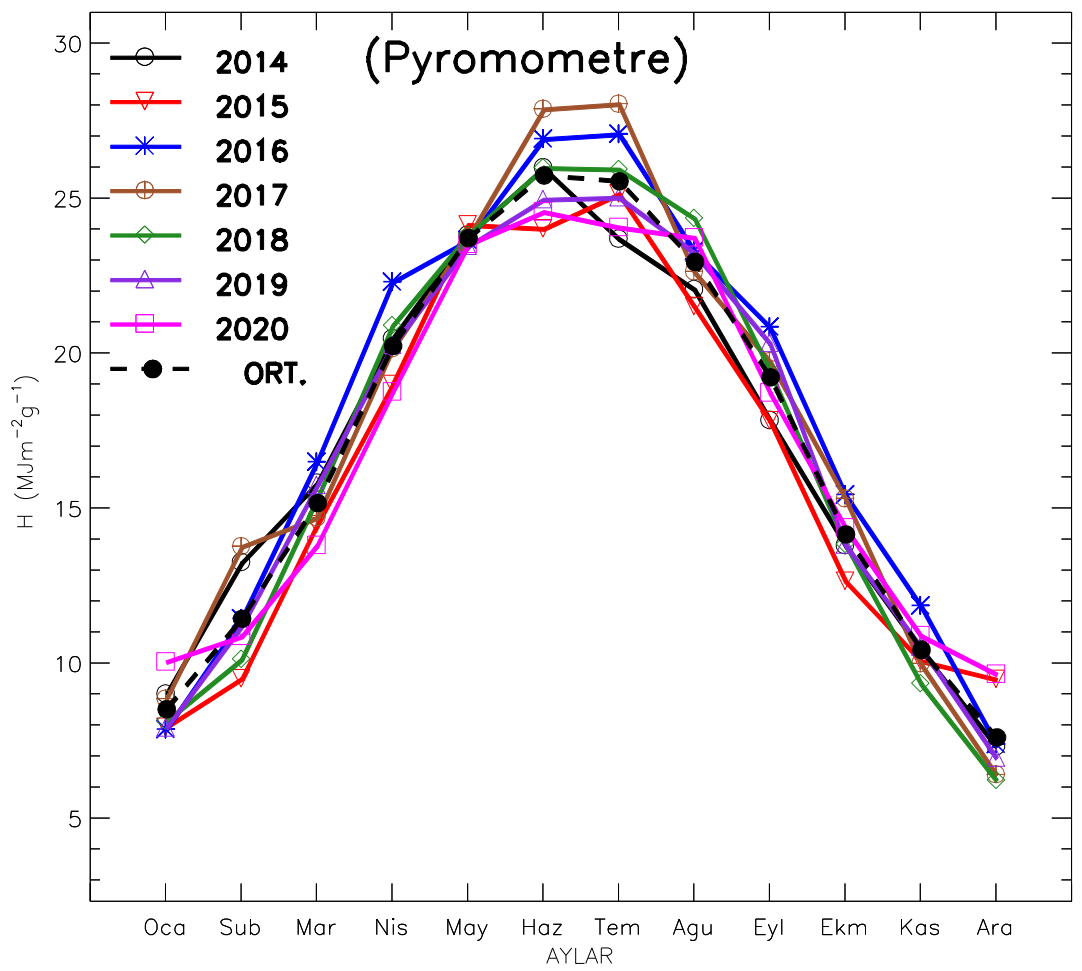

Şekil 4. 2014-2020 arasında ölçülen günlük güneş radyasyon $(\mathrm{H})$ verilerinin yıllara göre aylık olarak günlük ortalama değişimleri

Tablo 6. Atmosfer dişı $\left(\mathrm{H}_{0}\right)$, ölçülen $(\mathrm{H})$ ve modellerden hesaplanan güneş radyasyonu $\left(\mathrm{MJm}^{-2} \mathrm{~g}^{-1}\right)$

\begin{tabular}{lcclllllll}
\hline Aylar & $\mathbf{H}_{\mathbf{0}}$ & $\mathbf{H}$ & $\mathbf{M 1}$ & $\mathbf{M 2}$ & $\mathbf{M 3}$ & $\mathbf{M 4}$ & $\mathbf{M 5}$ & $\mathbf{M 6}$ & M7 \\
\hline Ocak & 16.24 & 8.54 & 7.98 & 8.28 & 8.74 & 8.57 & 9.25 & 8.48 & 8.53 \\
Şubat & 21.20 & 11.46 & 10.54 & 11.10 & 11.51 & 11.26 & 11.98 & 11.40 & 11.50 \\
Mart & 28.63 & 15.19 & 15.27 & 15.83 & 15.91 & 15.84 & 16.41 & 16.02 & 16.01 \\
Nisan & 34.49 & 20.26 & 19.45 & 20.10 & 19.70 & 19.75 & 20.18 & 20.45 & 20.41 \\
Mayıs & 41.29 & 23.74 & 25.11 & 25.43 & 24.32 & 24.94 & 25.25 & 25.53 & 25.18 \\
Haziran & 41.71 & 25.76 & 25.08 & 25.80 & 25.02 & 24.98 & 25.20 & 25.22 & 25.49 \\
Temmuz & 43.25 & 25.57 & 26.40 & 26.83 & 26.35 & 26.19 & 26.34 & 24.76 & 25.20 \\
Ăgustos & 38.25 & 22.97 & 23.45 & 23.35 & 23.38 & 23.25 & 23.38 & 22.15 & 22.56 \\
Eylül & 30.34 & 19.25 & 18.92 & 18.17 & 18.34 & 18.68 & 18.85 & 18.99 & 18.91 \\
Ekim & 24.10 & 14.18 & 14.00 & 13.53 & 14.10 & 14.08 & 14.30 & 15.22 & 15.31 \\
Kasım & 18.32 & 10.45 & 9.30 & 9.51 & 10.21 & 9.85 & 10.27 & 10.83 & 11.08 \\
Aralık & 15.62 & 7.63 & 7.44 & 7.84 & 8.45 & 8.11 & 8.64 & 8.15 & 8.35 \\
\hline
\end{tabular}

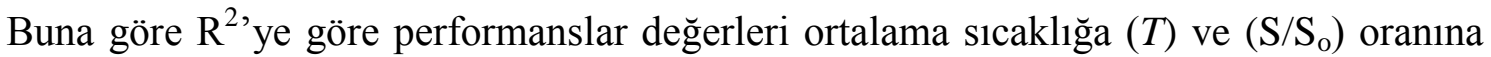
bağlı olan M3 de (0.9917) yaklaşık en iyi sonucu verdiği görülürken $\left(S / S_{0}\right)$ ve $\Delta \mathrm{T}$ (Tmax-Tmin) bağlı olan M2'de (0.9843) modelinin de en zayıf sonucu verdiği görülmüştür. Genel olarak tüm modellerden elde edilen performanslar ortalama $\mathrm{R}^{2}$ değerinin 0.9843 ile oldukça iyi sonuç verdiği görülmektedir. Tablo 7 incelendiğinde modellerden tahmin edilen güneş radyasyonlar istatistiksel hata sonuçları bir birlerine oldukça yakın sonuçlar gösterdiği görülmemektedir. Tek tek modellerin performanslarına bakıldığında, RMSE hata göstergesine göre, en doğru model $\mathrm{R}^{2}$ de olduğu gibi M3 $\left(0.5845 \mathrm{MJm}^{-2} \mathrm{~g}^{-1}\right)$ en az uygun ise M2 $\left(0.8021 \mathrm{MJm}^{-2} \mathrm{~g}^{-1}\right)$ olduğu görülmektedir. MBE için mutlak değer olarak sıfıra en yakın ve en uzak değerleri sirasıla M5 (0.0414 $\left.\mathrm{MJm}^{-2} \mathrm{~g}^{-1}\right)$ ve M2 $\left(0.4199 \mathrm{MJm}^{-2} \mathrm{~g}^{-1}\right)$ arasında hata göstergeleri vermektedir. MARE istatistiksel göstergesi en düşük ve en yüksek sırasıyla M5 (0.0302 $\left.\mathrm{MJm}^{-2} \mathrm{~g}^{-1}\right)$ ve M2 (0.0437 $\left.\mathrm{MJm}^{-2} \mathrm{~g}^{-1}\right)$ arasında hata göstergeleri vermektedir. MAE 
istatistiksel göstergeleri en düşük ve en yüksek sırasıyla M5 $\left(0.0035 \mathrm{MJm}^{-2} \mathrm{~g}^{-1}\right)$ ve M2 $\left(0.0350 \mathrm{MJm}^{-2} \mathrm{~g}^{-1}\right)$ arasında hata göstergeleri vermektedir. MPE için istatistiksel hata göstergeleri yüzde olarak en düşük ve en yüksek sırasıyla M5 (0.2440) ve M2 (3.3069) arasında performansa sahip olduğu görülmüştür. MPE için istatistiksel hata göstergeleri de yüzde olarak en düşük ve en yüksek sırasıyla M5 (0.0302) ve M2 (0.0437) arasında performansa sahip olduğu görülmüştür. Sonuç olarak, $\mathrm{R}^{2}$ ve RMSE istatistiksel hata göstergeleri M3 modelinin en iyi performans gösterirken MBE, MPE, MAPE, MARE ve MAE istatistiksel hata göstergelerinin en iyi performans gösteren modelin M5 olduğu görülmektedir.

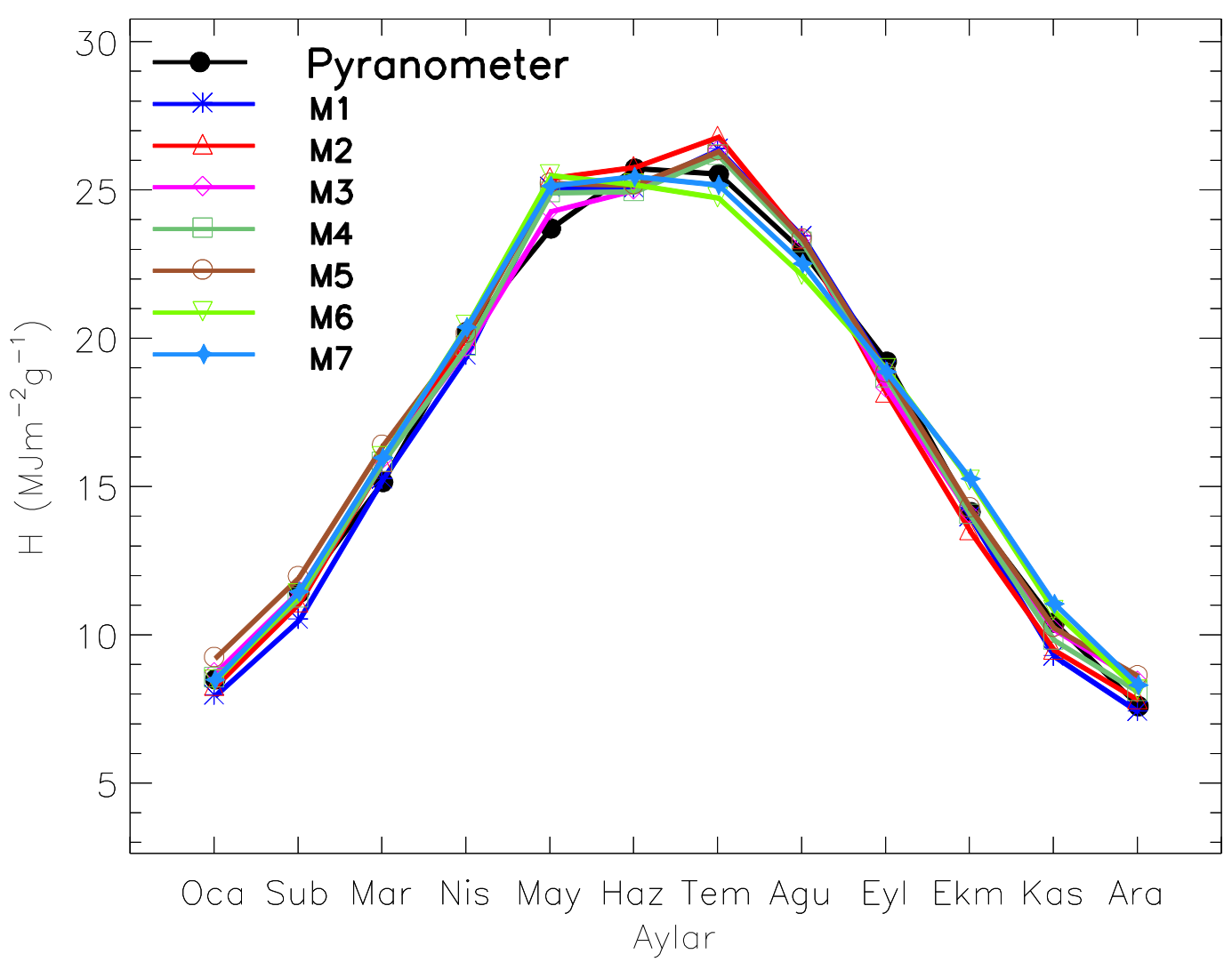

Şekil 5. Modellerden hesaplanan ve piranometre ile ölçülen güneş radyasyonu verilerinin aylara göre değişimi

Osmaniye için aylık ortalama günlük maksimum gün uzunluğu (saat/gün) $\left(\mathrm{S}_{0}\right)$ ve modellerden tahmin edilen aylık ortalama günlük açıklık endeksleri $\left(\mathrm{K}_{\mathrm{T}}\right.$, birimsiz) Tablo 8'de verilmiştir. Aylık ortalama günlük maksimum gün uzunluğu $\left(\mathrm{S}_{0}\right)$ Denklem (5)'den hesaplanmıştır. Tablo 8'de birinci sütunda hesaplanan aylık ortalama günlük maksimum gün uzunluğunun ( $\mathrm{S} 0$ ) en yüksek Haziran ve Temmuz aylarında (ortalama 14.502 saat ), en düşük değerleri ise Aralık ve Ocak aylarında (ortalama 9.63 saat ile) olduğu görülmüştür. Y1llık ortalama ise yaklaşık 12.00 saat olarak belirlenmiştir.

Açıklık endeksleri $\left(\mathrm{K}_{\mathrm{T}}\right)$ hesaplamak için Denklem (2)'de verilen atmosfer dişı güneş radyasyonu $\left(\mathrm{H}_{0}\right)$ değeri aylık olarak hesaplanana ve Tablo 6'daki birinci sütunda verilen $\mathrm{H}_{0}$ değerleri kullanılmıştır. Açıklık indeksi $\left(\mathrm{K}_{\mathrm{T}}\right)$ için Denklem (6) kullanılmıştır [2]. Bunun için ölçülen güneş radyasyonu $(\mathrm{H})$ atmosfer dişı güneş radyasyonuna $\left(\mathrm{H}_{0}\right)$ oranından $\left(K_{T}=\mathrm{H} / H_{0}\right)$ elde edilmiştir. Benzer şekilde modellerden hesaplanan güneş radyasyonları (M1-7) atmosfer dışı güneş radyasyonuna $\left(\mathrm{H}_{0}\right)$ bölünerek modeller için açıklık indeksleri $\left(K_{T}=H_{M} / H_{0}\right)$ elde edilmiştir. Açıklık indeks $\left(K_{T}\right)$ sonuçları Tablo 8 'de 
verilmiştir. Tablo 8'de verilen $\mathrm{K}_{\mathrm{T}}$ 'nin gözlemlenen ve modellerden tahmin edilen aylık ortalama günlük değerleri arasında karşılaştırılması Şekil 7'de verilmiştir.

Tablo 7. Modellerden tahmin edilen Güneş radyasyonlar istatistiksel hata sonuçları

\begin{tabular}{|c|c|c|c|c|c|c|c|}
\hline Model & $\begin{array}{l}\mathbf{R}^{2} \\
(\%)\end{array}$ & $\begin{array}{c}\text { RMSE } \\
\left(\mathrm{MJm}^{-2} \mathrm{~g}^{-1}\right)\end{array}$ & $\begin{array}{c}\mathrm{MBE} \\
\left(\mathrm{MJm}^{-2} \mathrm{~g}^{-1}\right)\end{array}$ & $\begin{array}{c}\text { MARE } \\
\left(\mathbf{M J m}^{-2} \mathbf{g}^{-1}\right)\end{array}$ & $\begin{array}{c}\text { MAE } \\
\left(\mathbf{M J m}^{-2} \mathbf{g}^{-1}\right)\end{array}$ & $\begin{array}{c}\text { MPE } \\
(\%)\end{array}$ & $\begin{array}{c}\text { MAPE } \\
(\%)\end{array}$ \\
\hline M5 & 0.9861 & 0.7549 & 0.0414 & 0.0302 & 0.0035 & 0.2440 & 3.0232 \\
\hline M4 & 0.9915 & 0.5881 & 0.0630 & 0.0391 & 0.0052 & 0.4525 & 3.9076 \\
\hline M1 & 0.9866 & 0.7415 & 0.0859 & 0.0323 & 0.0072 & 1.0262 & 3.2311 \\
\hline M6 & 0.9855 & 0.7697 & 0.1722 & 0.0412 & 0.0143 & 2.1778 & 4.1217 \\
\hline M7 & 0.9889 & 0.6733 & 0.1825 & 0.0359 & 0.0152 & 1.6896 & 3.5922 \\
\hline M3 & 0.9917 & 0.5845 & 0.2925 & 0.0351 & 0.0244 & 2.4733 & 3.5119 \\
\hline M2 & 0.9843 & 0.8021 & 0.4199 & 0.0437 & 0.0350 & 3.3069 & 4.3746 \\
\hline Ort. & 0.9878 & 0.7020 & 0.1796 & 0.0368 & 0.0150 & 1.6243 & 3.6803 \\
\hline
\end{tabular}

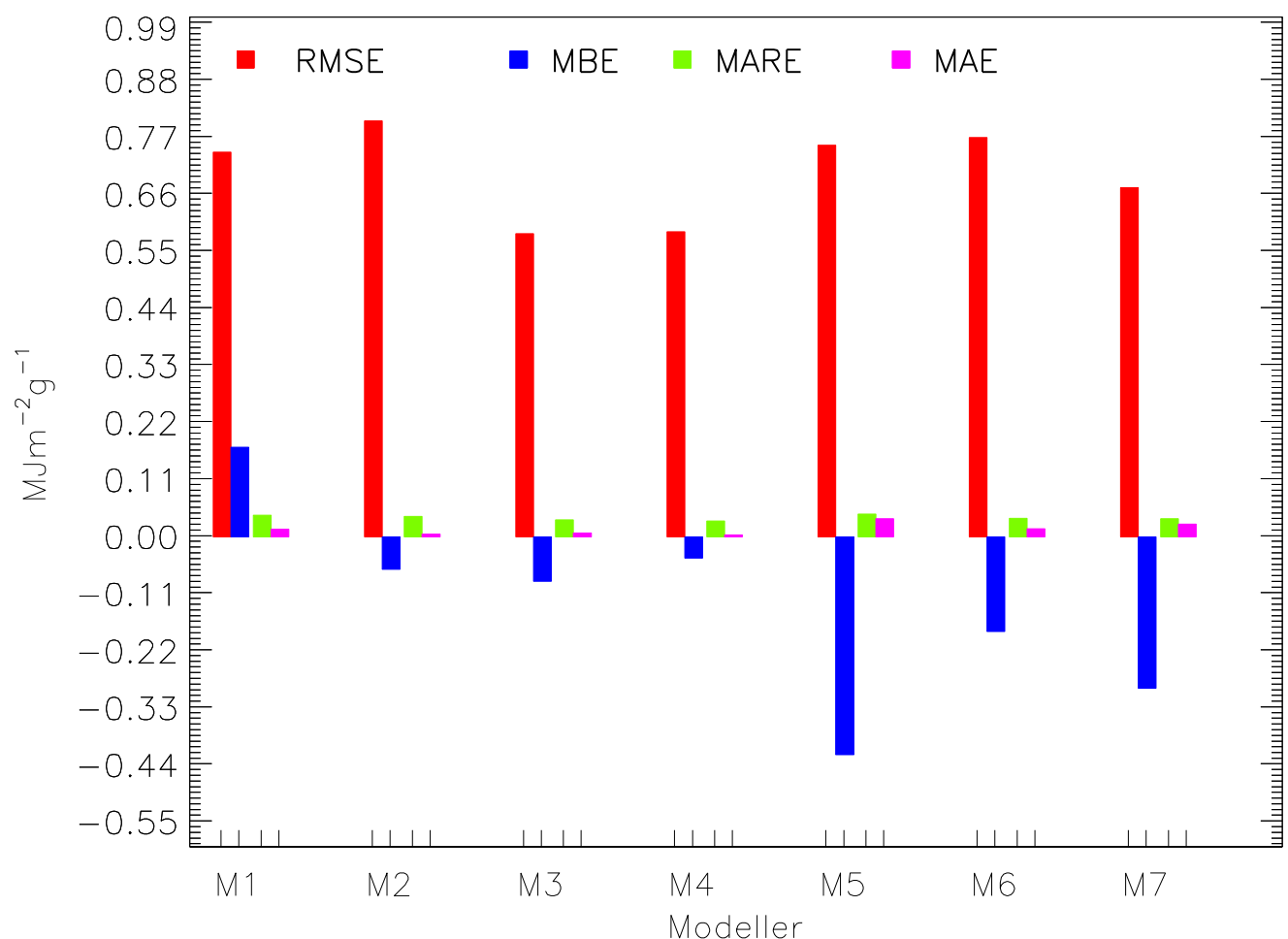

Şekil 6. Modellerden tahmin edilen Güneş radyasyonlar istatistiksel hata sonuçları

Ölçülen global güneş radyasyonu için açıklık indeksinin $\left(K_{T, H}\right)$ için minimum ve maksimum değerlerinin Aralık ayında (0.489), Ağustos'da 0.635 olduğu ve yıllık ortalama 0.571 olduğu tespit edilmiştir. M1'den hesaplanan güneş radyasyonu için açıklık indeksinin minimum ve maksimum değerlerinin $\left(K_{T, M 1}\right)$ Aralık ayında (0.476), Eylül'de 0.624 olduğu ve y1llık ortalama 0,559 olduğu tespit edilmiştir. M2'den hesaplanan açıklık indeksinin minimum ve maksimum değerlerinin $\left(K_{T, M 2}\right)$ Aralık ayında (0.502), Temmuz ayında 0.620 olduğu ve yıllık ortalama 0.568 olduğu tespit edilmiştir. M3 modelinden hesaplanan açıklık indeksinin $\left(K_{T, M 3}\right)$ minimum ve maksimum değerlerinin Ocak ayında (0.538), Ağustos ayında 0.611 olduğu ve yıllık ortalama 0.575 olduğu tespit edilmiştir. M4'den hesaplanan güneş radyasyonu için açıklık indeksinin minimum ve maksimum değerlerinin $\left(K_{T, M 4}\right)$ Aralık ayında (0.519), Eylül'de (0.616) olduğu ve yıllık ortalama 0.571 olduğu tespit edilmiştir. M5'den hesaplanan açıklık indeksinin $\left(K_{T, M 5}\right)$ minimum ve maksimum değerlerinin Aralık ayında (0.553), Eylül'de 0.621 olduğu ve yıllık ortalama 0.588 olduğu tespit edilmiştir. 
M6 modelinden hesaplanan açıklık indeksinin $\left(K_{T, M 6}\right)$ minimum ve maksimum değerlerinin Aralık ayında (0.522), Ekim'de 0.632 olduğu ve ylllık ortalama 0.580 olduğu tespit edilmiştir. M7'den hesaplanan açıklık indeksinin $\left(K_{T, M 7}\right)$ minimum ve maksimum değerlerinin Ocak ayında (0.525), Ekim'de 0.635 olduğu ve yıllık ortalama 0,584 olduğu tespit edilmiştir. Sonuç olarak, modellerden hesaplanan en düşük olduğu ay Aralık ayı ile Ocak ayı ve en yüksek olduğu aylar ise genel olarak Temmuz Ağustos, Eylül ve Ekim aylarında olduğu görülmüştür.

Tablo 8. Osmaniye için aylık ortalama günlük maksimum gün uzunluğu (saat) $\left(S_{0}\right)$ ve modellerden tahmin edilen aylık ortalama günlük açıklık endeksleri değerleri arasında karşılaştırılması ( $\mathrm{K}_{\mathrm{T}}$ : birimsiz).

\begin{tabular}{lccccccccc}
\hline Aylar & $\mathbf{S}_{\mathbf{0}}$ & $\mathbf{K}_{\mathbf{T , H}}$ & $\mathbf{K}_{\mathbf{T}, \mathbf{M} \mathbf{1}}$ & $\mathbf{K}_{\mathbf{T , M 2} \mathbf{2}}$ & $\mathbf{K}_{\mathbf{T}, \mathbf{M} 3}$ & $\mathbf{K}_{\mathbf{T , M 4}}$ & $\mathbf{K}_{\mathbf{T , M} \mathbf{M}}$ & $\mathbf{K}_{\mathbf{T , M 6}}$ & $\mathbf{K}_{\mathbf{T , M 7}}$ \\
\hline Ocak & 9.765 & 0.526 & 0.492 & 0.510 & 0.538 & 0.528 & 0.570 & 0.522 & 0.525 \\
Şubat & 10.667 & 0.541 & 0.497 & 0.524 & 0.543 & 0.531 & 0.565 & 0.538 & 0.542 \\
Mart & 11.757 & 0.531 & 0.533 & 0.553 & 0.556 & 0.553 & 0.573 & 0.559 & 0.559 \\
Nisan & 12.959 & 0.587 & 0.564 & 0.583 & 0.571 & 0.573 & 0.585 & 0.593 & 0.592 \\
Mayis & 13.984 & 0.575 & 0.608 & 0.616 & 0.589 & 0.604 & 0.611 & 0.618 & 0.610 \\
Haziran & 14.502 & 0.618 & 0.601 & 0.619 & 0.600 & 0.599 & 0.604 & 0.605 & 0.611 \\
Temmuz & 14.268 & 0.591 & 0.610 & 0.620 & 0.609 & 0.606 & 0.609 & 0.572 & 0.583 \\
Ağustos & 13.387 & 0.600 & 0.613 & 0.610 & 0.611 & 0.608 & 0.611 & 0.579 & 0.590 \\
Eylül & 12.223 & 0.635 & 0.624 & 0.599 & 0.605 & 0.616 & 0.621 & 0.626 & 0.623 \\
Ekim & 11.022 & 0.588 & 0.581 & 0.562 & 0.585 & 0.584 & 0.594 & 0.632 & 0.635 \\
Kasım & 10.002 & 0.570 & 0.507 & 0.519 & 0.557 & 0.537 & 0.560 & 0.591 & 0.605 \\
Aralık & 9.503 & 0.489 & 0.476 & 0.502 & 0.541 & 0.519 & 0.553 & 0.522 & 0.534 \\
\hline Yllık Ort. & 12.003 & 0.571 & 0.559 & 0.568 & 0.575 & 0.571 & 0.588 & 0.580 & 0.584 \\
\hline
\end{tabular}

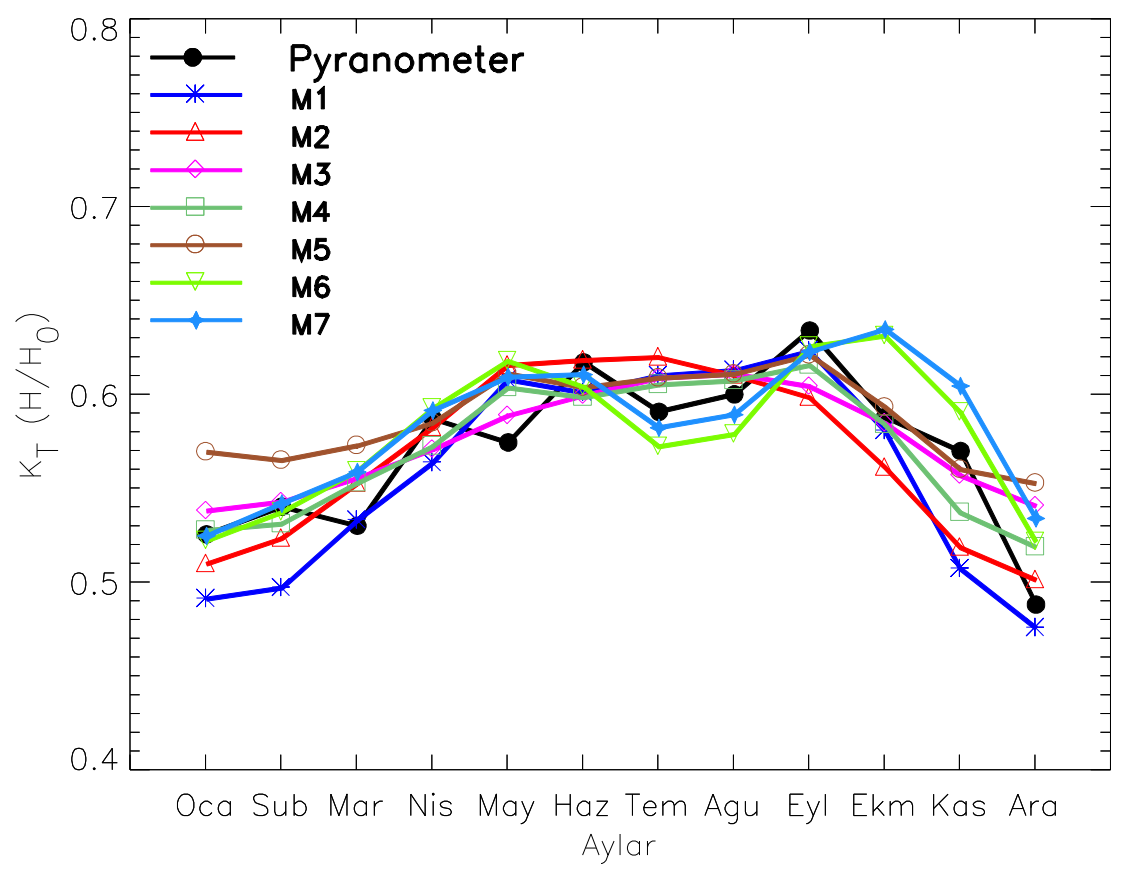

Şekil 7. $\mathrm{K}_{\mathrm{T}}$ 'nin gözlemlenen ve modellerden tahmin edilen aylık ortalama günlük değerleri arasında karşılaştırılması

\section{Sonuç ve Yorum}

$\mathrm{Bu}$ çalışmada Osmaniye ili (Enlem: $37^{\circ} .04227$, Boylam: $36^{\circ} .22134$ ) için yatay bir yüzeyde aylık ortalama günlük global güneş radyasyon ölçülmüş ve tahmini için modeller geliştirilmiştir. 
Global güneş radyasyon ölçümünde 8-48 Model Black\&White piranometre ölçüm cihazı kullanılmış ve Ocak 2014 ile Aralık 2020 yılları arasında toplam yedi yıllık yatay yüzeye gelen global güneş radyasyon verileri saatlik olarak günlük, aylık ve yıllık olarak incelenmiştir.

Buna göre, 2014-2020 arasında ölçülen günlük güneş radyasyon verilerinin y1llara göre saatlik olarak günlük ortalama değişimleri yıllara göre saatlik güneş radyasyonlarının ortalamaları 2014 yilında toplam $17.15 \mathrm{MJm}^{-2} \mathrm{~g}^{-1}$ (ort. $1.14 \mathrm{MJm}^{-2} \mathrm{~g}^{-1}$ ), 2015 toplam 16.71 $\mathrm{MJm}^{-2} \mathrm{~g}^{-1}$ (ort. $1.11 \mathrm{MJm}^{-2} \mathrm{~g}^{-1}$ ), 2016 y1lında $18.29 \mathrm{MJm}^{-2} \mathrm{~g}^{-1}$ (ort. $2.44 \mathrm{MJm}^{-2} \mathrm{~g}^{-1}$ ), 2018 y1lında $16.95 \mathrm{MJm}^{-2} \mathrm{~g}^{-1}$ (ort.1.13 $\mathrm{MJm}^{-2} \mathrm{~g}^{-1}$ ), 2019 y1lında toplami $17.96 \mathrm{MJm}^{-2} \mathrm{~g}^{-1}$ (ort. $1.20 \mathrm{MJm}^{-2} \mathrm{~g}^{-1}$ ) ve 2020 y1lında toplamı 16.92 $\mathrm{MJm}^{-2} \mathrm{~g}^{-1}$ (ort. $1.13 \mathrm{MJm}^{-2} \mathrm{~g}^{-1}$ ) olarak ölçülmüştür.

2014-2020 arasında ölçülen günlük güneş radyasyon verilerinin y1llara göre saatlik olarak günlük toplam değişimleri 2014 yılında $205.75 \mathrm{MJm}^{-2} \mathrm{~g}^{-1}$ (ort. $13.72 \mathrm{MJm}^{-2} \mathrm{~g}^{-1}$ ), 2015 y1linda $197.83 \mathrm{MJm}^{-2} \mathrm{~g}^{-1}$ (ort. $13.19 \mathrm{MJm}^{-2} \mathrm{~g}^{-1}$ ), 2016 yllinda $219.50 \mathrm{MJm}^{-2} \mathrm{~g}^{-1}$ (ort. 14.63 $\mathrm{MJm}^{-2} \mathrm{~g}^{-1}$ ), 2017 y1linda 211.20 $\mathrm{MJm}^{-2} \mathrm{~g}^{-1}$ (ort.14.08 $\mathrm{MJm}^{-2} \mathrm{~g}^{-1}$ ), 2018 y1linda $203.44 \mathrm{MJm}^{-2} \mathrm{~g}^{-1}$ (ort. $13.56 \mathrm{MJm}^{-2} \mathrm{~g}^{-1}$ ), 2019 y1lında $207.46 \mathrm{MJm}^{-2} \mathrm{~g}^{-1}$ (ort. $13.83 \mathrm{MJm}^{-}$ ${ }^{2} \mathrm{~g}^{-1}$ ) ve 2020 y1lında $203.02 \mathrm{MJm}^{-2} \mathrm{~g}^{-1}$ (ortalama $13.53 \mathrm{MJm}^{-2} \mathrm{~g}^{-1}$ ) olarak ölçülmüştür. 2014-2020 yılları arasındaki ortalama yıllık olarak saatlik toplamları $1448.19 \mathrm{MJm}^{-2} \mathrm{~g}^{-1}$ ve ortalamaları $96.55 \mathrm{MJm}^{-2} \mathrm{~g}^{-1}$ olduğu bulunmuştur.

2014-2020 yılları arasındaki yedi yıllık olarak aylık olarak ortalama aylık güneş radyasyon değişimlerinin ortalaması incelendiğinde yedi yıllık ortalamaları incelendiğinde aylık olarak toplam $205.01 \mathrm{MJm}^{-2} \mathrm{~g}^{-1}$ ve ortalama $17.08 \mathrm{MJm}^{-2} \mathrm{~g}^{-1}$ olarak elde edilmiştir. Toplam güneş radyasyonu Haziran $\left(25.76 \mathrm{MJm}^{-2} \mathrm{~g}^{-1}\right)$ en yüksek ve Aralık (7.63 $\left.\mathrm{MJm}^{-2} \mathrm{~g}^{-1}\right)$ en düşük olmuştur. Aylık ortalama günlük parlak güneş 1şı̆̆ (S) saatlerinin minimum ve maksimum değerleri 3.54 ve 12.28 olarak kaydedildi.

Devlet Meteoroloji İşleri Genel Müdürlüğü’nden elde edilen 1987-2020 y1lları arasındaki ortalama maksimum, ortalama minimum ve ortalama sicaklık $\left({ }^{\circ} \mathrm{C}\right)$ verileri ile ortalama güneşlenme süresi (saat) verileri kullanılarak Osmaniye $\left(\phi=37^{\circ} .04227\right)$ ilinin aylık olarak ortalama güneş radyasyonu tahmin yedi farklı ampirik formül modeli (M17) geliştirilmiş ve 2014-2020 yılları arasında ölçülen yıllık ortalamaların aylık değişimleri ile karşılaştırılmıştır. $R^{2}$ ve RMSE istatistiksel hata göstergeleri M3 modelinin en iyi performans gösterirken MBE, MPE, MAPE, MARE ve MAE istatistiksel hata göstergelerinin en iyi performans gösteren modelin M5 olduğu görülmektedir. Ayrıca, ölçülen ve tahmin edilen aylık global güneş radyasyonu için açılklı indeksi de $\left(\mathrm{KT}=\mathrm{H} / \mathrm{H}_{0}\right)$ hesaplanmış ve ölçülen radyasyon için $0,511<K_{T, H}<0,634$ ve modellerden hesaplanan KT oran1 M5 için $0.553<K_{T, M 5}<0.621$ ve M3 için $0.538<K_{T, M 3}<0.611$ olarak bulunmuştur.

Ölçülen ve tahmin edilen güneş radyasyon değerleri arasındaki uyum oldukça iyi olduğu görülmüş ve geliştirilen bu modellerin (özellikle M5 ( $\left./ \mathrm{S}_{0}, \mathrm{~T}\right)$ ve M3 $\left(S / S_{0}\right.$, $T_{\max }\left(T_{\min }\right)$ ) herhangi bir yerde veya Türkiye'nin güneyindeki benzer iklime sahip bölgelerde kullanılması önerilmektedir.

\section{Araştırmacıların Katkı Oranı Beyanı}

Muhittin ŞAHAN: Araştırma, Veri Temini, Veri Analizi, Orjinal Taslak Yazımı, İnceleme ve Düzenleme, Görselleştirme.

Nuri EMRAHOĞLU: Araştırma, Kaynak, Materyal, Analiz, Araştırma. 


\section{Çatışma Beyanı}

Bu çalışmanın yazarları olarak herhangi bir çatışma beyanımız bulunmadığını bildiririz.

\section{Etik Kurul Onayı ve Aydınlatılmış Onam Bilgileri}

$\mathrm{Bu}$ çalışmanın yazarları olarak herhangi bir etik kurul onayı ve/veya aydınlatılmış onam bilgileri beyanımız bulunmadığını bildiririz.

\section{Kaynakça}

[1] J. A. Duffie and W. A. Beckman, Solar Engineering of Thermal Processes. (4th ed.), John Wiley and Sons, Inc., New York, 2013.

[2] M. Iqbal, An Introduction to Solar Radiation. London: Academic Press, 1983.

[3] Q. Schiermeier, J. Tollefson, T. Scully, A. Witze, and O. Morton, "Energy alternatives: Electricity without carbon," Nature, 454, 816-23, 2008.

[4] M. Xiao, Z. Yu, and Y. Cui, "Evaluation and estimation of daily global solar radiation from the estimated direct and diffuse solar radiation," Theoretical and Applied Climatology, 140, 983-992, 2020.

[5] J. Fan, L. Wu, F. Zhang, H. Cai, X. Ma, and H. Bai "Evaluation and development of empirical models for estimating daily and monthly mean daily diffuse horizontal solar radiation for different climatic regions of China," Renew Sustain Energy Rev., 105, 168-186, 2019.

[6] J. Almorox and C. Hontoria, "Global solar radiation estimation using sunshine duration in Spain," Energy Conversion and Management, 45, 1529-1535, 2004.

[7] O. Şenkal and T. Kuleli, "Estimation of solar radiation over Turkey using artificial neural network and satellite data," Applied Energy, 86, 1222-1228, 2009.

[8] O. Şenkal, "Solar radiation modeling for Turkey using atmospheric parameters with artificial neural networks,” Çukurova Üniversitesi Mühendislik-Mimarlik Fakültesi Dergisi, 31 (2), 179-185, 2016.

[9] A. Bandyopadhyay, A. Bhadra, N.S. Raghuwanshi, and R. Singh, "Estimation of monthly solar radiation from measured air temperature extremes," Agricultural and Forest Meteorology, 148, 1707-1718, 2008.

[10] G. H. Hargreaves and Z. A. Samani, "Estimating potential evapotranspiration," J. Irrig. Drain. Eng., 108 (3), 225-230, 1982.

[11] M. Şahan, H. Şahan ve İ. Yegingil, "Yıllık toplam ve ultraviole (UV) güneş enerjisi verilerinin ölçülmesi," Süleyman Demirel Üniversitesi, Fen Bilimleri Enstitüsü Dergisi,14 (1), 10-16, 2010.

[12] M. Şahan, "Measurement of daily solar radiation with Eppley Black and White pyranometer in Osmaniye Region, Turkey", AIP Conference Proceedings 2018, 2042, pp. 020005-1-0200054, 2018.

[13] M. Şahan, Ö. Tokat, ve Y. Okur, "Osmaniye'de günlük toplam güneş 1şınım ölçümleri," SDU Journal of Science, 10 (2), 97-105, 2015.

[14] M. Despotovic, V. Nedic, D. Despotovic, and S. Cvetanovic, "Review and statistical analysis of different global solar radiation sunshine models," Renewable and Sustainable Energy Reviews, 52, 1869-1880, 2015.

[15] A. Angström, "Solar and terrestrial radiation," Quarterly Journal of the Royal Meteorological Society, 50 (210), 121-126, 1924.

[16] J. A. Prescott, "Evaporation from a water surface in relation to solar radiation," Transactions of the Royal Society of South Australia, 64, 114-148, 1940.

[17] M. R. Rietveld, "A new method for estimating the regression coefficients in the formula relating solar radiation to sunshine," Agricult. Meteorol., 19, 243-252, 1978.

[18] H. Ogelman, A. Ecevit, and E. Tasdemiroglu, "A new method for estimating solar radiation from bright sunshine data," Solar Energy, 33, 619-625, 1984.

[19] B. G. Akinoglu, A. Ecevit, "A further comparison and discussion of sunshine based models to estimate global solar radiation", Solar Energy, 15, 865-872, 1990.

[20] J. Glover and J. D. G. McGulloch, "The empirical relation between solar radiation and hours of sunshine", Q. J. Roy. Meteorol. Soc., 84, 172-175, 1958.

[21] R. De Jong and D. W. Stewart, "Estimating global solar radiation from common meteorological observations in western Canada," Can. J. Plant. Sci., 73, 509-518, 1993.

[22] K. L. Bristow and G. S. Campbell, "On the relationship between incoming solar radiation and daily maximum and minimum temperature," Agric. For. Meteorol., 31, 159-166, 1984.

[23] S. Klein, "Calculation of monthly average insolation on tilted surfaces," Solar Energy, 19 (4), $325-$ 329, 1977. 
[24] J. R. Howell, R. B. Bannerot, and G. C. Vliet, Solar-Thermal Energy Systems Analysis and Design, McGraw-Hill, Inc., New York, 1982.

[25] N. Emrahoğlu ve İ. Yeğingil, "Çukurova Üniversitesi’nde ölçülen güneş 1şınım verileri analizi," Çukurova Üniversitesi Mühendislik Mimarlık Fakültesi Dergisi, 34 (2), 87-96, 2019.

[26] https://www.mgm.gov.tr/kurumici/radyasyon_iller.aspx

[27] C. Ertekin and O. Yaldiz, "Comparison of some existing models for estimating global solar radiation for Antalya (Turkey)," Energy Convers Mgmt., 41, 311-330, 2000.

[28] D. B. Ampratwum and A. S. S. Dorvlo, "Estimation of solar radiation from the number of sunshine hours," Appl. Energy, 62, 161-167, 1990. 